\title{
Syngas biomethanation: state-of-the-art review and perspectives
}

\section{Grimalt Alemany, Antonio; Skiadas, loannis V; Gavala, Hariklia N.}

Published in:

Biofuels, Bioproducts and Biorefining

Link to article, DOI:

$10.1002 / \mathrm{bbb} .1826$

Publication date:

2018

Document Version

Peer reviewed version

Link back to DTU Orbit

Citation (APA):

Grimalt Alemany, A., Skiadas, I. V., \& Gavala, H. N. (2018). Syngas biomethanation: state-of-the-art review and perspectives. Biofuels, Bioproducts and Biorefining, 12(1), 139-158. https://doi.org/10.1002/bbb.1826

\section{General rights}

Copyright and moral rights for the publications made accessible in the public portal are retained by the authors and/or other copyright owners and it is a condition of accessing publications that users recognise and abide by the legal requirements associated with these rights.

- Users may download and print one copy of any publication from the public portal for the purpose of private study or research.

- You may not further distribute the material or use it for any profit-making activity or commercial gain

- You may freely distribute the URL identifying the publication in the public portal

If you believe that this document breaches copyright please contact us providing details, and we will remove access to the work immediately and investigate your claim 


\title{
Syngas biomethanation: state of the art review and perspectives
}

\author{
Antonio Grimalt-Alemany ${ }^{1}$, Ioannis V. Skiadas ${ }^{2}$, Hariklia N. Gavala $^{1 *}$ \\ ${ }^{1}$ Center for Bioprocess Engineering, Department of Chemical and Biochemical Engineering, Technical \\ University of Denmark, Søltofts Plads 229, 2800 Kgs. Lyngby, Denmark \\ ${ }^{2}$ PILOT PLANT, Department of Chemical and Biochemical Engineering, Technical University of \\ Denmark, Søltofts Plads 229, 2800 Kgs. Lyngby, Denmark \\ *E-mail: $\underline{\text { hnga@kt.dtu.dk, hari_gavala@yahoo.com }}$
}

\begin{abstract}
Significant research efforts are currently being made worldwide in order to develop more efficient biomethane production processes from a variety of waste streams. The biomethanation of biomassderived syngas can contribute to increase the potential of the methane production as it opens the way for the conversion of recalcitrant biomasses, generally not fully exploitable by anaerobic digestion systems. Additionally, this biological process presents a number of advantages over its analogous process of catalytic methanation such as the use of inexpensive biocatalysts, milder operation conditions, higher tolerance to the impurities of syngas and higher product selectivity. However, there are still several challenges to be addressed in order for this technology to reach a commercial stage. This work reviews the progress made over the last years in syngas biomethanation processes in order to provide an overview of the current state of the art of this technology. The most relevant aspects determining the performance of syngas biomethanation processes are extensively discussed here, including microbial diversity and metabolic interactions in mixed microbial consortia, the influence of
\end{abstract}


REVIEW ON SYNGAS BIOMETHANATION

operating parameters and bioreactor designs, and the potential of modelling as a tool for the design and control of this bioprocess.

Keywords: biomethanation, synthesis gas, carbon monoxide, methane, microbial consortia, mixed cultures

\section{Introduction}

The increase in energy demand over the last decades along with the foreseen future scarcity of fossil fuels and the climate crisis have driven policymakers to foster the production of biofuels as an alternative energy source. Currently, several countries with an important role in the global market have implemented policies in this direction, including US, EU, Brazil, China and India among others. ${ }^{1}$ An example of such policies is the European Directive 2009/28/EC, which established binding targets for achieving a $20 \%$ share of energy from renewable sources on the overall European energy consumption by 2020 , and a minimum share of $10 \%$ in the transport sector emphasizing the need of promoting second generation biofuels. Therefore, the current legal and regulatory framework poses an important window of opportunity for the development of an alternative technological infrastructure based on the use of non-food biomasses and waste streams as feedstock.

One of the most promising approaches within second and third generation biofuel technologies is the process of gas fermentation, which has gained increasing interest in recent years for the conversion of both industrial off-gases and recalcitrant feedstocks when coupled to their gasification into synthesis gas. This process consists in the fermentation of a gaseous substrate, mainly composed by $\mathrm{H}_{2}, \mathrm{CO}$ and $\mathrm{CO}_{2}$, carried out by anaerobic microorganisms able to utilize these gases as a carbon and energy source. 
Acetogenic bacteria are currently the predominant microbial group subject to study in syngas fermentation processes, with ethanol being the most commonly targeted product. Syngas fermentation processes for the production of ethanol ${ }^{2-8}$ and other products, such as acetone, butanol, 2,3-butanediol and even biopolymers, have been extensively reviewed recently including several process development related aspects such as bioreactor design, relevant operational parameters and genetic tools for broadening the product portfolio of the syngas bioconversion. ${ }^{9-15}$ However, the biological process of syngas conversion into methane is often overlooked in these reviews despite the research carried out in this field over the last years. Therefore, the scope of this article is to perform a comprehensive review of the knowledge available up-to-date in syngas biomethanation processes in order to provide an overview of the current state of the art of this technology, as well as to discuss about its future application perspectives.

As a potential product, biogas (or biomethane when upgraded) presents a significant potential for its integration into the current biofuel landscape due to its versatility as energy carrier. Up to date, the most common practice is to exploit biogas in-situ for production of combined heat and power as the quality standards for this application are generally lower. However, biogas upgrading to biomethane provides a more flexible application of this fuel, as biomethane and natural gas are fully miscible in the natural gas grid. As a transportation fuel, the use of biomethane in bi-fuel cars is a rather attractive alternative to liquid fuels in terms of energy content (table 1). Additionally, the fact that it is fully miscible with its fossil analogue, natural gas, is a clear advantage over other liquid biofuels such as bioethanol or biodiesel, which are usually blended to some extent in conventional cars. ${ }^{16}$ On the other hand, its further development as an automotive fuel is currently hindered by several factors such as the early stage of its commercial market, the limited number of filling stations, and the high cost of the 
technological transfer to bi-fuel vehicles compared to vehicles fueled by solely ethanol. ${ }^{17,18}$ However, the positive trend in the use of biomethane as a vehicle fuel in several European countries, e.g. Sweden, France or Denmark, ${ }^{19}$ anticipates the expansion of this emerging market, which could foster the development of more efficient production processes.

Table 1. Energy content of various fuels. ${ }^{20}$

\begin{tabular}{lc}
\hline Fuel & $\begin{array}{c}\text { Higher Heating Value } \\
(\mathbf{M J} / \mathbf{k g})\end{array}$ \\
\hline Gasoline & 46.5 \\
Diesel & $45.4^{\mathrm{a}}$ \\
Ethanol & 29.7 \\
Biodiesel & $42.2^{\mathrm{a}}$ \\
Methane & 55.5 \\
Hydrogen & 141.8 \\
Butanol & $36.6^{\mathrm{a}}$ \\
Dimethyl Ether & 31.7 \\
Methanol & $22.7^{\mathrm{a}}$ \\
\hline \multicolumn{2}{l}{ Extracted from Demirel. ${ }^{21}$}
\end{tabular}

An additional aspect of biomethane is its flexibility in terms of production paths and biomass sources, as it can be produced by both biochemical and thermochemical methods which separately and in combination may cover a wide range of feedstocks of different nature. Anaerobic digestion is a wellestablished technology currently processing several feedstock types from the agricultural sector and other organic industrial waste streams. ${ }^{22}$ On the other hand, catalytic methanation technologies for Synthetic Natural Gas (SNG) production have been revisited over the last 10 years due to the rising prices of natural gas and the need of addressing energy security issues, which has promoted the development of several new catalytic methanation processes based on biomass gasification. ${ }^{23}$ These facts suggest that the process of syngas biomethanation would also have a potential market for its future application once it reached commercial scale. As it will be discussed in the next section, this technology presents several advantages over the analogous catalytic methanation process and is also 
REVIEW ON SYNGAS BIOMETHANATION

well suited for coupling to current anaerobic digestion systems, opening thus good perspectives for further development of this technology.

\section{Overview of the syngas biomethanation process}

The biomethanation of biomass-derived syngas is a robust bioconversion route combining the benefits of thermochemical and biochemical conversion processes, as it circumvents the limitations of the biological degradation of complex substrates by gasifying the biomass into a directly fermentable gas. The thermochemical conversion of the feedstock through gasification constitutes one of the main advantages since any type of biomass can be gasified including agricultural residues, forestry residues, non-fermentable byproducts from biorefineries, byproducts of any bioprocessing facility and even organic municipal wastes. ${ }^{24}$ However, the substrate of the syngas biomethanation process is not limited to biomass-derived syngas, as there are other potential sources of CO-rich industrial off-gases in the iron and steel sector. ${ }^{25}$ Alternatively, other industrial $\mathrm{CO}_{2}$-rich off-gases could also be used as substrate along with $\mathrm{H}_{2}$ derived from the surplus of renewable electricity, opening another potential application as a means of storing renewable electricity. ${ }^{26}$ Therefore, there is a rather wide range of industrial offgas sources and biomasses that could be used as feedstock for this process.

The biomethanation of syngas involves the synergistic action of microorganisms, integrated in a mixed microbial consortium, for the utilization of syngas as a carbon and energy source to synthesize a mixture of methane and carbon dioxide. The biomethanation of syngas is a strictly anaerobic process that can be carried out at both mesophilic and thermophilic conditions. Synthesis gas is converted into methane both directly and stepwise through intermediary products by a number of microbial groups such as methanogenic archaea, acetogenic bacteria and hydrogenogenic bacteria among others, with all 
of them thriving in syntrophic association. As a result, the biomethanation of syngas comprises a complex network of biochemical reactions mainly based on the water-gas shift reaction, acetogenesis, hydrogenotrophic methanation, carboxydotrophic methanation and acetoclastic methanation. Despite the higher complexity of microbial consortia compared to pure cultures, the adoption of this mixed culture approach presents a series of inherent merits such as non-sterile operation, higher adaptation capacity, higher tolerance to the impurities of the raw syngas and resiliency after a disturbance in the operating conditions; which represent a crucial advantage when it comes to maintain the productivity of a continuous process. ${ }^{12,27,28}$ Additionally, using undefined mixed microbial consortia renders continuous processes more robust, as their adaptation to the substrate selects the most efficient and effective biocatalysts leading to a long-term improved performance of the microbial consortium. ${ }^{28}$

\subsection{Syngas biomethanation versus catalytic methanation}

The catalytic methanation is an exothermic process using hydrogen and carbon oxides present in syngas for the catalytic production of methane and water. This process operates at temperatures above $250^{\circ} \mathrm{C}$ and high pressures, using previously activated metallic catalysts in order to drive the catalytic reduction of carbon oxides into methane. The catalysts used in methanation are very sensitive to the impurities present in synthesis gas such as chlorine and sulfur compounds, ammonia, tars and particles; which ultimately cause poisoning and deactivation of the catalysts. ${ }^{29}$ Therefore, the catalytic methanation requires an intensive gas cleaning process of the raw syngas before entering the reactor. Furthermore, an additional water-gas shift reaction process is often needed in order to correct the ratio of $\mathrm{C} / \mathrm{H}$ in syngas, which reduces the overall efficiency of the process while increasing the complexity and the cost of operation. ${ }^{30}$ The use of biocatalysts in syngas biomethanation is anticipated to result in a more cost-effective process as these present a higher tolerance to the impurities of syngas and operate 
at mild temperatures. As opposed to the catalytic process, the biological process is not sensitive to the ratio of $\mathrm{C} / \mathrm{H}$ since the water-gas shift reaction is inherent to the autotrophic metabolism of most microbial groups ${ }^{31}$ conducting the biomethanation of syngas. Additionally, the biomethanation presents a higher selectivity as methane and carbon dioxide are the only end-products of the fermentation, whereas the catalytic process produces higher hydrocarbons as byproducts. Lastly, the irreversible character of the biochemical reactions during biomethanation allows the complete conversion of the substrates, this way avoiding the thermodynamic equilibrium limitations of the

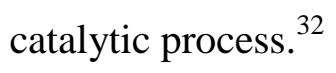

\subsection{Coupling syngas biomethanation and anaerobic digestion}

Anaerobic digestion is so far the default technology for biological production of methane, holding the dual role of waste treatment and production of biofuels process. ${ }^{33}$ The degradation of organic residues in anaerobic digestion is carried out by undefined mixed microbial consortia in four consecutive stages, namely hydrolysis, acidogenesis, acetogenesis and methanogenesis. Continuous anaerobic digestion processes are generally characterized by long hydraulic retention times due to the presence of refractory compounds in the biomass, which make hydrolysis the main rate-limiting step of the digestion. ${ }^{34}$ Nevertheless, the main limiting factor is often the low biomass conversion efficiency due to the low degradability of some specific biomasses. Thus, pretreatments are usually needed in order to enhance the digestibility of the biomass and improve the hydrolysis yield. In turn, the syngas biomethanation process circumvents the limitations of the biological degradation of complex substrates by gasifying the biomass into a directly fermentable gas, overcoming the aforementioned shortcomings. Nonetheless, these technologies are not necessarily alternative as their integration in a combined process seems a promising configuration for achieving a more efficient production of methane. Li et 
al. ${ }^{30}$ studied the feasibility of combining the anaerobic digestion of source-separated organic waste with the gasification and biomethanation of wood pellets to increase both quality and productivity of biomethane, obtaining a potential increase of $161 \%$ in the production of biomethane compared to the stand-alone anaerobic digestion process. Similarly, Guiot et al. ${ }^{35}$ estimated the potential of the conversion of municipal solid waste through anaerobic digestion of the easily digestible organic fraction and syngas biomethanation of the non-digestible organic fraction, resulting in a production of biomethane of about five times higher than the stand-alone anaerobic digestion of municipal solid waste. Other potential benefits are the use of biochar produced during the thermochemical treatment of the biomass as a support for biofilm formation or as an in-situ biogas upgrading agent during the anaerobic digestion process. ${ }^{36,37}$ Therefore, there are several synergies that could be exploited upon the combination of these technologies.

\section{Progress in syngas biomethanation and ongoing research}

Despite the potential benefits of the syngas biomethanation process, there are still important bottlenecks that need to be addressed in order for this technology to be commercially applicable. One of the main shortcomings of continuous syngas fermentation processes is the limited mass transfer rate of $\mathrm{H}_{2}$ and $\mathrm{CO}$ due to the low solubility of these gases in the liquid medium. The low cell growth rate of anaerobic microorganisms is another limiting factor since the low cell productivities of continuous processes result in low volumetric productivities of $\mathrm{CH}_{4}$. The fundamental aspects of the microbial metabolism of the microorganisms carrying out the biomethanation of syngas have been thoroughly studied over the last decades. Yet, studies on the behavior of microbial consortia under different operating conditions still need to be conducted in order to improve our understanding of the microbial 
interactions within microbial consortia and achieve an optimal performance in microbial consortiadriven processes. The effect of operational parameters such as $\mathrm{pH}$, temperature, gas partial pressure and syngas impurities were recently reviewed in the frame of syngas fermentation to ethanol and other products. ${ }^{2,4,5,38,39}$ Thus, this review focuses on the progress made in the abovementioned aspects of syngas biomethanation processes over the last years, laying special emphasis on the role of microbial interactions within syngas-converting mixed microbial consortia.

\subsection{Microbial growth on synthesis gas and syntrophic relationships in undefined mixed microbial consortia}

The main components of synthesis gas $\left(\mathrm{H}_{2}, \mathrm{CO}_{2}\right.$ and $\left.\mathrm{CO}\right)$ can sustain growth of a wide array of microorganisms belonging to different ecological niches such as certain fungi, ${ }^{40}$ algae, ${ }^{41}$ photosynthetic bacteria $^{42}$ hydrogenogenic bacteria ${ }^{43}$ and archaea, ${ }^{44}$ sulfate-reducing bacteria ${ }^{45}$ and archaea, ${ }^{46}$ acetogenic bacteria ${ }^{47}$ and methanogenic archaea ${ }^{48}$ among others. However, during anaerobic growth only acetogens, methanogens, sulfate-reducers and hydrogenogens can use either $\mathrm{CO}$ or $\mathrm{H}_{2} / \mathrm{CO}_{2}$ as the

sole carbon and energy source. ${ }^{49,50}$ These groups are physiologically and phylogenetically diverse, although they all share common metabolic features such as the fact that acetyl-CoA plays a central role during the assimilation of both $\mathrm{H}_{2} / \mathrm{CO}_{2}$ and $\mathrm{CO}$ in all of them, and $\mathrm{CO}$ itself is a necessary intermediate for the fixation of $\mathrm{CO}_{2}$ by acetogens and methanogens. ${ }^{51-53}$ Therefore, the presence of $\mathrm{CO}$ dehydrogenases $(\mathrm{CODH})$ is also a common thread in the metabolism of these microorganisms. However, the function of their $\mathrm{CODH}$ differs in that they can either oxidize $\mathrm{CO}$, synthesize acetyl-CoA or cleave acetyl-CoA in a variety of independent energy-yielding pathways in each of these microbial groups. $^{54}$ 
The anaerobic assimilation of $\mathrm{CO}$ and $\mathrm{H}_{2} / \mathrm{CO}_{2}$ can be categorized in the following four distinct activities according to their final metabolic product: hydrogenogenesis (including hydrogenogenic bacteria and archaea, and carboxydotrophic hydrogenogenic sulfate-reducers ${ }^{55}$ ), sulfidogenesis (including carboxydotrophic sulfidogenic sulfate-reducers ${ }^{52,55}$ ), carboxydotrophic and hydrogenotrophic acetogenesis ${ }^{56,57}$ and carboxydotrophic and hydrogenotrophic methanogenesis ${ }^{52,58}$. The biochemistry of these respiratory processes has been extensively reviewed by several researchers in recent years. ${ }^{52,53,55-59}$ Thus, this section focuses on the microbial interactions prevailing in syngasconverting microbial consortia during the production of methane.

A microbial consortia-driven process of syngas biomethanation sustains a variety of microbial groups, such as the above mentioned, which develop a chain of syntrophic interactions resulting in the production of $\mathrm{CH}_{4}$ as the only end product of the fermentation. Thus, the conversion of syngas into $\mathrm{CH}_{4}$ can take place either directly through the conversion of both $\mathrm{CO}$ and $\mathrm{H}_{2} / \mathrm{CO}_{2}$ by carboxydotrophic and hydrogenotrophic methanogenesis, or indirectly through the conversion of syngas into methanogenic precursors such as acetate, $\mathrm{H}_{2}$ and formate, followed by aceticlastic and hydrogenotrophic methanogenesis. Additionally, acetogenic bacteria have been reported to produce other by-products besides acetate, like ethanol, ${ }^{60}$ butyrate $^{61}$ and butanol, ${ }^{62}$ which could be further converted into acetate and ultimately into $\mathrm{CH}_{4}$. Therefore, a microbial consortium may convert syngas into $\mathrm{CH}_{4}$ through a complex network of interconnected biochemical reactions as shown in fig. 1. However, the microbial interactions within a stable and structured microbial consortium do not simply consist of cross-feeding relationships, as there are other possible microbial interactions besides crossfeeding, like synergistic interactions between different species and mutual exclusion relationships between metabolically competitive populations. 


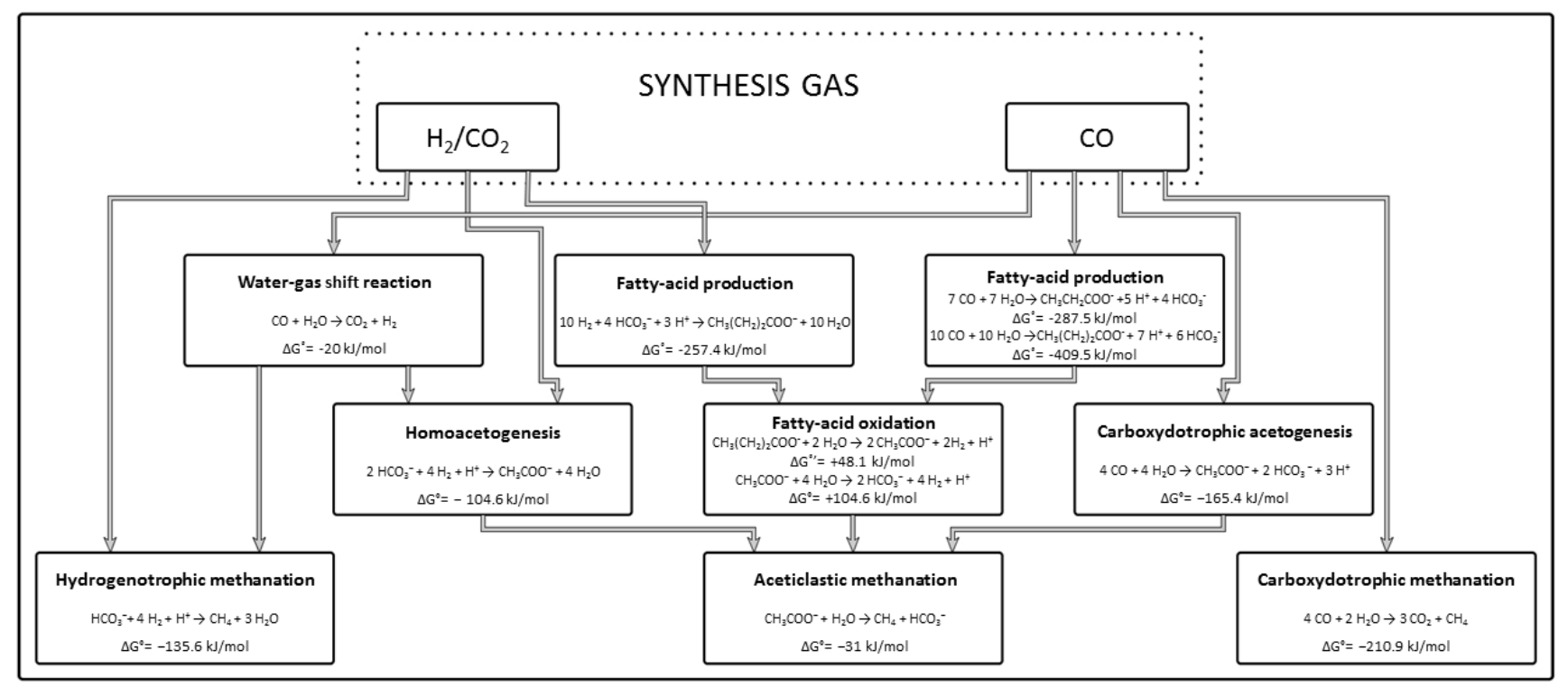

Figure 1. Pathways leading to the production of methane. The standard Gibbs free energy change $\left(\Delta G^{\circ}\right)$ was calculated according to Thauer et al. ${ }^{89}$

\subsubsection{Cross-feeding relationships}

Despite the multiple pathways through which syngas can be converted into $\mathrm{CH}_{4}$, several studies have reported the preferential use of certain pathways within the consortium during the biomethanation of syngas. Guiot \& Cimpoia ${ }^{64}$ evaluated the mesophilic and thermophilic methanogenic potential of anaerobic granules from a UASB plant during the conversion of $\mathrm{CO}$ and syngas, observing that $\mathrm{CO}$ was predominantly converted through hydrogenotrophic methanogenesis combined with CO-dependent $\mathrm{H}_{2}$ formation. In this study, formation of volatile fatty acids (VFA) was also observed, although only in trace amounts consisting of mainly acetate; however, when $\mathrm{H}_{2}$ and $\mathrm{CO}_{2}$ were also added as substrates, the amount of VFA's produced increased. In turn, Navarro et al. ${ }^{65}$ found that CO was converted into $\mathrm{CH}_{4}$ through acetate as a main intermediary product during inhibition experiments (based on the use of BES and vancomycin for inhibiting the methanogenesis and acetogenesis, respectively) at mesophilic conditions using a similar anaerobic granular sludge. These results are in line with the findings of other studies using the same inhibitors, in which acetate was found to be the main intermediate product 
during the conversion of $\mathrm{CO}$ into $\mathrm{CH}_{4}$ at mesophilic conditions, and $\mathrm{H}_{2}$ at thermophilic conditions. ${ }^{66}$ All these studies concluded that the carboxydotrophic methanogenic activity was negligible for the anaerobic sludges tested. Similar results were obtained while studying the structure and diversity of microbial consortia on a simultaneous process of thermophilic anaerobic digestion of sewage sludge and $\mathrm{CO}$ biomethanation, in which the population of hydrogenotrophic methanogens increased upon addition of $\mathrm{CO}$ into the bioreactor due to the higher production of $\mathrm{H}_{2}$ from $\mathrm{CO} .{ }^{67}$ In turn, in a similar study at mesophilic conditions, Wang et al. ${ }^{68}$ found that the addition of $\mathrm{CO}$ in the bioreactor resulted in a clear increase of hydrogenotrophic microbial groups while the population of aceticlastic methanogens remained at high levels. They concluded that $\mathrm{CO}$ was converted to both $\mathrm{H}_{2}$ and acetate, which were further converted into $\mathrm{CH}_{4}$ by both direct hydrogenotrophic methanogenesis, and indirect acetogenesis and aceticlastic methanogenesis. Thus, it appears that the biomethanation of syngas by mixed microbial consortia generally takes place through indirect conversion rather than direct, with acetate and $\mathrm{H}_{2}$ being the most common methanogenic precursors.

\subsubsection{Mutualistic interactions}

There are still other possible metabolic interactions exhibiting mutualistic properties that could be developed among different members of a mixed microbial consortium. An example of such mutualistic relationships is the interspecies diffusion of electron carriers like $\mathrm{H}_{2}$ or formate between syntrophic bacteria and methanogenic archaea, which could remain unnoticed due to the low concentration and fast turnover of these compounds. ${ }^{69}$ The syntrophic bacterial genus Smithella, a fatty acid-oxidizer, was found to be relatively dominant during the simultaneous biomethanation of sewage sludge and CO; however, whether its function was relevant to the biomethanation of $\mathrm{CO}$ was not determined. ${ }^{68}$ Similarly, Navarro et al. ${ }^{70}$ found that the population of Geobacter unaniireducens, a syntrophic acetate- 
oxidizing bacterium, increased in a granular sludge after a long-term exposure to $\mathrm{CO}$. The process of interspecies diffusion of electron carriers was studied by Boone et al. ${ }^{69}$ in co-culture experiments with the fatty acid-oxidizing bacterium $S$. wolfei and the methanogen $M$. formicicum using butyrate as substrate. When these species were co-cultured, the production of $\mathrm{CH}_{4}$ proceeded exponentially while the concentration of $\mathrm{H}_{2}$ remained constant at $63 \mathrm{nM}$ until depletion of butyrate, after which the concentration of $\mathrm{H}_{2}$ dropped to $35 \mathrm{nM}^{69}$ Similarly in the same study, a co-culture of $S$. wolfei and Desulfovibrio sp. strain GII was incubated with butyrate and sulfate as substrates, where the concentration of $\mathrm{H}_{2}$ stabilized at $27 \mathrm{nM}$ for 2 days until sulfate was depleted. This illustrates the importance that such interspecies diffusion of electron carriers may have during the conversion of fatty acids to methanogenic precursors in mixed microbial consortia. However, the Gibbs free-energy change for e.g. butyrate oxidation to acetate, $\mathrm{H}_{2}$ and $\mathrm{CO}_{2}$ is only favorable at very low $\mathrm{P}_{\mathrm{H} 2}\left(<10^{-4} \mathrm{~atm}\right)$. This type of symbiotic relationship is thus only feasible in those cases in which $\mathrm{H}_{2}$ is kept at low concentrations due to the continuous removal of $\mathrm{H}_{2}$ by e.g. hydrogenotrophic methanogens. Nonetheless, recent studies have demonstrated that Geobacter species and Methanosaeta species are capable of direct interspecies electron transfer as an alternative mechanism to $\mathrm{H}_{2}$ or formate transfer. ${ }^{71}$

Further symbiotic interactions have also been reported in other co-culture experiments. Parshina et al. ${ }^{72}$ found that the pure cultures of $D$. kuznetsovii and D. thermobenzoicum subsp. thermosyntrophicum were capable of chemolithotrophic growth on $\mathrm{CO}$ levels up to $0.70 \mathrm{~atm}$ when cultivated in presence of sulfate. However, when these species were co-cultured with $C$. hydrogenoformans, they were able to grow at $1 \mathrm{~atm}$ of $\mathrm{CO}$ through the reduction of sulfate using the $\mathrm{H}_{2}$ produced by the hydrogenogen. ${ }^{72}$ Similar results were obtained by Rajagopal et al. ${ }^{73}$ who studied the co-culture of D. vulgaris and $M$. barkeri in absence of sulfate. The pure culture of $D$. vulgaris exhibited partial inhibition of the 
production of $\mathrm{H}_{2}$ from pyruvate upon addition of $\mathrm{CO}$ to the culture, as the rate of $\mathrm{H}_{2}$ production from pyruvate alone and from both substrates remained unchanged. Nonetheless, when $D$. vulgaris was cocultured with $M$. barkeri using lactate as substrate, the injection of $\mathrm{CO}$ resulted in a $\mathrm{H}_{2}$ burst along with a parallel increase in the rate of $\mathrm{CH}_{4}$ production with no apparent inhibitory effect of $\mathrm{CO} .{ }^{73}$ Additional symbiotic interactions have also been observed in experiments using undefined mixed microbial consortia. Navarro et al. ${ }^{70}$ compared the performance of crushed granular sludge and whole sludge granules fed on $\mathrm{CO}$, finding that the higher organization of the granular sludge enhanced the $\mathrm{CH}_{4}$ production rate due to the protection of the inner layers of the granule against the toxicity of CO. Therefore, these cases show that the metabolic interaction between microbial groups can generate synergistic effects due to the lower concentration of $\mathrm{CO}$ in the medium or in the inner layers of the granules, enhancing both the growth and the resiliency of the microbial community as a whole.

\subsubsection{Mutual exclusion interactions}

The structure of a microbial consortium is not only determined by interactions of mutualistic nature since mutual exclusion relationships, based on competition for common substrates, also play an important role on the definition of the community structure. In presence of sulfate, all active microbial groups during syngas biomethanation including acetogens, methanogens, sulfate-reducers and hydrogenogens compete for common substrates such as $\mathrm{CO}, \mathrm{H}_{2}$ or acetate. The competition for $\mathrm{H}_{2}$ is generally ruled by sulfate-reducers, since both the kinetic properties of this group and the thermodynamics of sulfate reduction are more favorable than in homoacetogenesis and methanogenesis. ${ }^{74,75}$ However, in most cases the activity of sulfate-reducers can be easily suppressed by controlling the sulfate content in the medium in order to favor the methanogenesis given the low content of sulfur oxides in syngas. According to $\mathrm{Xu}$ et al., ${ }^{38}$ the highest concentration of sulfur 
compounds reported in biomass-derived syngas corresponds to $0.055 \mathrm{~mol} \%$ for $\mathrm{SO}_{2}$, and $0.0001 \mathrm{~mol} \%$ for $\mathrm{H}_{2} \mathrm{~S}$ and COS. Moreover, the outcome of the competition for $\mathrm{H}_{2}$ appears to depend on additional factors, since in contrast to the previous statement hydrogenotrophic methanogens have also been reported to outcompete sulfate-reducers. Sipma et al. ${ }^{76}$ observed that sulfate-reducers were clearly outcompeted by hydrogenotrophic methanogens during operation of a gas-lift reactor fed on $\mathrm{CO}$ and sulfate at thermophilic conditions. In this study, the dominance of hydrogenotrophic methanogens was attributed to the higher growth rates of this microbial group at the operating conditions investigated. ${ }^{76}$ The competition between homoacetogens and hydrogenotrophic methanogens for $\mathrm{H}_{2}$ was studied by Liu et al. ${ }^{77}$, finding that the kinetic constants $K_{s}$ and $\mu_{\max }$ of homoacetogens were respectively 10 times higher and 4 times lower than those of hydrogenotrophic methanogens. Hence, homoacetogens were clearly outcompeted by the latter group under substrate-limiting conditions (low $\mathrm{P}_{\mathrm{H} 2}$ ). However, homoacetogens were able to compete for $\mathrm{H}_{2}$ at high $\mathrm{P}_{\mathrm{H} 2}$, contributing through aceticlastic methanogenesis to the formation of $40 \%$ of the $\mathrm{CH}_{4}$ produced. $^{77}$

The competition for $\mathrm{CO}$ in mixed microbial consortia has not been thoroughly studied, although the outcome of the competition can be predicted based on the kinetic properties reported for these microbial groups. Carboxydotrophic methanogens typically have long doubling times ranging from 24 h to 200 h..$^{48,78}$ In turn, the doubling times exhibited by acetogenic bacteria generally oscillate between $1.5 \mathrm{~h}$ and $16 \mathrm{~h}$ reported for $R$. Productus and $C$. thermoaceticum, respectively. ${ }^{79,80}$ Hydrogenogenic growth supports different doubling times depending on the microbial group, being $1-2 \mathrm{~h}$ for thermophilic hydrogenogens and $4.8 \mathrm{~h}-8.4 \mathrm{~h}$ for phototrophic bacteria. ${ }^{81,82,76}$ Therefore, the comparison of the growth kinetics on $\mathrm{CO}$ of these microbial groups indicates that methanogens will be easily outcompeted in a mixed microbial consortium. However, it is likely that the outcome of the 
competition between hydrogenogenic and acetogenic bacteria is not ultimately dependent upon their kinetics given the similarity of the doubling times reported.

All these microbial interactions can have an influence, either positive or negative, on the structure and diversity of a microbial community, ultimately affecting the performance of the consortium. Therefore, knowledge on the type of interactions prevailing among the members of a microbial consortium is fundamental for the control and optimization of the process. ${ }^{83}$ However, the performance of a consortium is also strongly influenced by the operating conditions of the process, thus requiring the integration of all aspects determining the outcome of the process for optimal process control.

\subsection{Influencing factors in syngas biomethanation}

The operating parameters of biological processes have a strong impact on the performance of the culture in terms of productivity as these affect several aspects of microbial growth. Pure culture-based processes are generally operated at conditions favoring optimal growth and productivity based on the characteristics and requirements of a particular strain. However, the members composing a mixed microbial consortium for syngas biomethanation rarely share the same optimal growth conditions, which make the selection of operational parameters a critical step when it comes to optimizing the process. In this section, the influence of parameters such as temperature, $\mathrm{pH}$ and gas composition on the $\mathrm{CH}_{4}$ yield and production rate of syngas-converting consortia is reviewed.

\subsection{1. $\mathrm{pH}$}

The $\mathrm{pH}$ is an important parameter for microbial growth due to its influence on the regulation of the metabolism and the bioenergetics of microorganisms as it causes changes in the intracellular $\mathrm{pH}$ and the electrochemical gradient across the membrane. Acetogenic bacteria are perhaps the most versatile 
microbial group as they are able to tolerate a wide range of $\mathrm{pH}$ including both acidic and alkaline conditions, ${ }^{56}$ although they are known to shift their generally acidogenic metabolism towards solventogenesis when decreasing the $\mathrm{pH}^{84,85}$ The hydrogenogenic microbial group including phototrophic and hydrogenogenic bacteria generally exhibit optimal growth at neutral $\mathrm{pH}^{55}$ In turn, most methanogens grow optimally at either neutral or slightly alkaline $\mathrm{pH}$ ranging from 6.8 to $8.5{ }^{58}$ being partially inhibited when decreasing the $\mathrm{pH}$. Consequently, most syngas biomethanation processes are operated at $\mathrm{pH}$ close to neutrality, between 7.0 and 7.6, in order to favor the methanogenesis and avoid the accumulation of liquid products (table 2). Nevertheless, the influence of the $\mathrm{pH}$ has not been thoroughly studied in syngas biomethanation processes. So far, only Pereira et al. ${ }^{86}$ have investigated the biomethanation of syngas using a mixed culture approach under different $\mathrm{pH}$ conditions. This study reported that the combination of low $\mathrm{pH}$ and high pressures of syngas $(2.5 \mathrm{~atm})$ resulted in high inhibition of the methanogenic activity, obtaining the lowest production of $\mathrm{CH}_{4}$ among all conditions tested. $^{86}$

\subsubsection{Temperature}

The temperature is one of the most influential factors in syngas biomethanation processes as it affects several aspects of the performance of mixed microbial consortia. As mentioned above, the temperature of the broth has been reported to have an effect on the microbial interactions among members of microbial consortia as it appears to determine the predominant metabolic pathways used by the consortia. Several studies on biomethanation of $\mathrm{CO}$ indicate that acetate is the main precursor of the methanogenesis at mesophilic conditions, whereas $\mathrm{H}_{2}$ is a more relevant precursor at thermophilic conditions. This could be explained by the higher diversity of carboxydotrophic hydrogenogenic bacteria in thermophilic environments. However, another possible explanation could be the fact that 
$\mathrm{H}_{2}$-producing reactions become more exergonic with increasing temperatures ${ }^{87}$, favoring a higher hydrogenogenic conversion of $\mathrm{CO}$ at thermophilic conditions. In either case, it has been shown that these changes in the microbial structure of the consortia due to higher temperatures lead to higher conversion rates in syngas biomethanation processes. Guiot \& Cimpoia ${ }^{64}$ compared the rates of $\mathrm{CH}_{4}$ production of a granular sludge at mesophilic and thermophilic conditions, finding that the $\mathrm{CH}_{4}$ productivity at thermophilic conditions $\left(5.6 \mathrm{mmol} / \mathrm{g} \mathrm{VSS} / \mathrm{d}\right.$ at $\left.60^{\circ} \mathrm{C}\right)$ was much higher than that at mesophilic conditions $\left(1 \mathrm{mmol} / \mathrm{g} \mathrm{VSS} / \mathrm{d}\right.$ at $\left.35^{\circ} \mathrm{C}\right)$. Similarly, another study investigated the correlation between the rates of conversion of $\mathrm{CO}$ and the temperature, observing that the rates of conversion of $\mathrm{CO}$ and the productivity of $\mathrm{CH}_{4}$ increased gradually from $40^{\circ} \mathrm{C}$ onwards until a maximum was reached at $55^{\circ} \mathrm{C} .{ }^{66}$ Nonetheless, despite the higher conversion rate and productivity, the increase in temperature also poses certain drawbacks related to the lower solubility of the gases, which could lead to mass transfer limitations in thermophilic processes.

\subsubsection{Gas partial pressure}

The effects of the composition of synthesis gas are mainly associated with mass transfer processes of the constituents of syngas, which are dependent on both the mass transfer coefficient $\left(k_{L} a\right)$ and consequently on the characteristics of the reactor, and the partial pressure of these gases as the driving force for their transportation to the liquid phase. In this section the effects of the partial pressures of the main components of syngas are discussed, while the effects of the mass transfer rates are addressed in the section for process configurations.

Carbon monoxide, besides being a substrate for carboxydotrophs, is also a well-known inhibitor for most carboxydotrophic microbial groups. Carboxydotrophic methanogens and sulfate-reducers appear to be the most sensitive, tolerating partial pressures of $\mathrm{CO}\left(\mathrm{P}_{\mathrm{CO}}\right)$ between $0.5-1.0$ atm and 0.2-0.5 atm 
respectively, with some exceptions..$^{45,48,78,88}$ In turn, both acetogens and hydrogenogens exhibit a higher tolerance to $\mathrm{CO}$, generally being able to grow at $\mathrm{P}_{\mathrm{CO}}$ higher than $1 \mathrm{~atm} .{ }^{4,55}$ Nevertheless, the effects of $\mathrm{CO}$ on syngas biomethanation processes are not limited to direct inhibition of carboxydotrophic growth, as other non-carboxydotrophic microbial groups with a significant role might also be affected, including fatty-acid oxidizing bacteria, aceticlastic and hydrogenotrophic methanogenic archaea.

In syngas biomethanation processes, the increase in $\mathrm{P}_{\mathrm{CO}}$ generally results in partial inhibition, ultimately affecting the yield and the productivity of $\mathrm{CH}_{4}$. The effects on the $\mathrm{CH}_{4}$ yield were evaluated on a mesophilic granular sludge fed on syngas, in which a decline in the $\mathrm{CH}_{4}$ yield was observed while increasing the total pressure of syngas from 1 to 2.5 atm due to the inhibition of the methanogenic activity. ${ }^{86}$ In turn, the specific carboxydotrophic and methanogenic activities of a mesophilic granular sludge under different initial $\mathrm{P}_{\mathrm{CO}}$ were studied by Navarro et al. ${ }^{70}$, observing that the rate of consumption of $\mathrm{CO}$ increased with the amount of $\mathrm{CO}$ supplied until a maximum was reached at a $\mathrm{P}_{\mathrm{CO}}$ of $0.5 \mathrm{~atm}$. However, the rate of production of $\mathrm{CH}_{4}$ reached its maximum at 0.2 atm of $\mathrm{CO}$, followed by a gradual decline along with the increase of $\mathrm{P}_{\mathrm{CO}}$ until the methanogenic activity was totally inhibited at 1 atm of $\mathrm{CO}^{70}$ Additionally, in this study a shift in the metabolic pathways with increasing $\mathrm{P}_{\mathrm{CO}}$ was observed, in which aceticlastic methanogenesis was displaced by hydrogenotrophic methanogenesis between 0.5 and $1 \mathrm{~atm}$. Thus, these studies clearly show that $\mathrm{CO}$ exerts a strong inhibitory effect over all microbial groups of the microbial consortium. Nevertheless, the differences observed between the carboxydotrophic and the methanogenic activities illustrate a distinctive inhibition over aceticlastic methanogens, which appear to be less tolerant than acetogenic, hydrogenogenic bacteria and hydrogenotrophic methanogenic archaea. The lower tolerance of the methanogenic group was also evident during the enrichment of a thermophilic methanogenic microbial consortium using increasing 
amounts of syngas along the successive transfers. ${ }^{89}$ In these experiments, both $\mathrm{H}_{2} / \mathrm{CO}_{2}$ and $\mathrm{CO}$ were initially converted into $\mathrm{CH}_{4}$ as the only end product. However, the enriched consortium lost its methanogenic activity at the fourth transfer due to the inhibition caused by the increasing partial pressure of syngas, resulting in the production of $\mathrm{H}_{2}$ as an intermediate product and the accumulation of acetate and propionate as end products. ${ }^{89}$

The concentration of $\mathrm{H}_{2}$ seems to have a milder influence on the performance of the consortium, although changes in the $\mathrm{P}_{\mathrm{H} 2}$ have been reported to have an effect on the microbial activity. The activity of the hydrogenase of a clostridial species denoted as $\mathrm{P} 11$ was studied under increasing $\mathrm{P}_{\mathrm{H} 2}$, finding that higher $\mathrm{P}_{\mathrm{H} 2}$ enhanced the activity of the hydrogenase. ${ }^{90}$ However, the efficiency of the hydrogenase decreased as the pressure of $\mathrm{H}_{2}$ built up due to the saturation of the enzyme. ${ }^{90}$ These findings are in line with the results of other experiments using a mixed culture approach, in which the production rate of $\mathrm{CH}_{4}$ increased sensibly from $0.035 \mathrm{mmol} / \mathrm{h}$ to $0.072 \mathrm{mmol} / \mathrm{h}$ upon an increase of the initial pressure of $\mathrm{H}_{2} / \mathrm{CO}_{2}$ from 1 to $5 \mathrm{~atm},{ }^{91}$ as it can be noted that the increase in the productivity appears not to correspond proportionally to the increase of pressure. Therefore, it is likely that the hydrogenases of other $\mathrm{H}_{2}$-utilizing microorganisms, e.g. hydrogenotrophic methanogens, are also affected by high $\mathrm{P}_{\mathrm{H} 2}$ resulting in lower rates of conversion. Additionally, in this study the structure of the microbial community was found to be affected by the $\mathrm{P}_{\mathrm{H} 2}$, reducing its diversity as the pressure of $\mathrm{H}_{2}$ increased due to the more stringent conditions. ${ }^{91}$

\subsubsection{Impurities of synthesis gas}

An additional aspect of the composition of syngas is the content of impurities typically found in the raw syngas, which may affect the process of syngas biomethanation either causing perturbations in the performance of the consortia or altering the operating parameters such as $\mathrm{pH}$ or redox. Impurities such 
as tars, $\mathrm{NOx}$ and $\mathrm{NH}_{3}$ have been found to inhibit the activity of several enzymes in acetogenic bacteria. $^{38,92,93}$ On the other hand, the sulfur gases $\mathrm{H}_{2} \mathrm{~S}$ and COS barely affected the growth and the substrate uptake rate of the acetogen $R$. productus and the methanogen $M$. barkeri, whereas the hydrogenogen $R$. rubrum and the methanogen $M$. formicicum were strongly inhibited even at low concentrations of these gases. ${ }^{94}$ Thus, each of the microbial groups appears to be affected differently by the impurities. Guiot et al. ${ }^{95}$ studied the effects of $\mathrm{HCN}, \mathrm{NH}_{3}, \mathrm{H}_{2} \mathrm{~S}$ and aromatic hydrocarbons on the overall performance of a methanogenic anaerobic sludge. The results of this study showed that the performance of the mixed culture was not significantly affected at levels below 500 ppm, 50 ppm and 1 ppm of $\mathrm{NH}_{3}, \mathrm{H}_{2} \mathrm{~S}$ and aromatic hydrocarbons, respectively. However, $\mathrm{HCN}$ was found to inhibit the aceticlastic methanogenic activity at levels below 15 ppm. It was thus concluded that aceticlastic methanogens were generally the most sensitive microbial group, although the activity of all microbial groups was inhibited at higher levels of these impurities. Despite it has been shown that the activity of microbial consortia is not significantly affected by low levels of impurities, further research in this area is still necessary in order to establish the minimum gas clean-up requirements of raw syngas as these may have an important influence on the overall efficiency of syngas biomethanation processes.

Some of the influencing factors discussed here, such as the effect of the temperature and the growth inhibition due to high $\mathrm{P}_{\mathrm{CO}}$, have been studied thoroughly in microbial consortia-driven syngas biomethanation processes. Nevertheless, studies on the influence of $\mathrm{pH}$ and the impurities of syngas are still very limited. Additionally, other factors such as the redox potential and the trace metal content of the media that have been studied in pure culture experiments, ${ }^{96,97}$ have not been investigated yet in microbial consortia. Studying the potential interactions among the influencing factors discussed in this section could also provide more insights on possible synergistic effects on the behavior of microbial 
consortia. Therefore, further research on both the influencing factors and their potential interactions is still necessary in order to fully comprehend their influence over the performance of each microbial group and the consortium as a whole.

\subsection{Process configurations}

Besides the limitations related to the inhibitory effects of $\mathrm{CO}$ and other aforementioned factors, syngas biomethanation processes are often restricted by poor gas-to-liquid mass transfer and low cell concentrations in the reactor, which ultimately reduce the volumetric productivity of $\mathrm{CH}_{4}$. In an attempt to address these shortcomings, syngas biomethanation processes have been studied in a number of process configurations including both batch and continuous operating modes and several reactor designs, each one of them having specific drawbacks and advantages. The main characteristics, yields and $\mathrm{CH}_{4}$ productivities obtained in such process configurations are summarized in table 2. Different syngas fermentation process configurations and bioreactor design issues have been reviewed before for the production of $\mathrm{H}_{2}$, ethanol and other potential products. ${ }^{2,4,9,98}$ Therefore, this article covers only the findings related to syngas biomethanation.

\subsubsection{Stirred-tank reactors}

The traditional stirred-tank reactors have been widely used in syngas fermentation processes. ${ }^{60,99-101}$ In this type of reactor, the volumetric mass transfer coefficient $\left(\mathrm{K}_{\mathrm{L}} \mathrm{a}\right)$ is affected by several factors such as the geometry of the reactor, the impeller configuration, the agitation speed and the gas flow rate. Typically, higher mass-transfer rates are attained by increasing both the agitation speed and the gas flow rate, which increase the gas-liquid interfacial area due to the smaller size of the bubbles. Klasson et al. ${ }^{32}$ studied the influence of these parameters on the $\mathrm{K}_{\mathrm{L}}$ a during the biomethanation of $\mathrm{CO}$ using a 
triculture of $R$. rubrum, M. formicicum and M. barkeri. The $\mathrm{K}_{\mathrm{L}}$ a was observed to increase from $28.1 \mathrm{~h}^{-1}$ to $101.1 \mathrm{~h}^{-1}$ when increasing the agitation speed from $300 \mathrm{rpm}$ to $450 \mathrm{rpm}$. However, the authors also observed that the efficiency in the conversion of $\mathrm{CO}$ decreased sharply while the gas loading rate increased, being $90 \%$ the maximum conversion efficiency reported at a gas loading rate of around 0.2 $\mathrm{h}^{-1}$. It can be thus concluded that although relatively high $\mathrm{K}_{\mathrm{L}}$ a values are attainable in this type of reactors, a high productivity of $\mathrm{CH}_{4}$ can only be achieved at the expense of low conversion efficiencies owing to the high gas flow rate needed. An alternative strategy for increasing the productivity of $\mathrm{CH}_{4}$ is to increase of the concentration of microbial biomass in the bioreactor. This possibility was studied in a continuous process of biomethanation of $\mathrm{H}_{2}$ and $\mathrm{CO}_{2}$ using a mixed culture from sewage sludge by including a cell recycling stream into the bioreactor. ${ }^{102}$ The cell recycle resulted in an increase of the cell concentration from $2.5 \mathrm{~g} / \mathrm{L}$ to $8.3 \mathrm{~g} / \mathrm{L}$, boosting the volumetric productivity of $\mathrm{CH}_{4}$ from 1.3 $\mathrm{L}_{\mathrm{CH} 4} / \mathrm{L} / \mathrm{h}$ to $4 \mathrm{~L}_{\mathrm{CH} 4} / \mathrm{L} / \mathrm{h}$. Therefore, an increase in the productivity of $\mathrm{CH}_{4}$ can be achieved through both cells recycling and enhancing the gas-to-liquid mass transfer. Other considerations such as the cost of operation should also be accounted when scaling up a process as the high energy requirements of maintaining a high mixing regime in large scale stirred tank reactors often can render this process not economically feasible. ${ }^{9}$

\subsubsection{Trickle-bed reactors}

Trickle-bed reactors are a suitable alternative to stirred tank reactors in terms of costs of operation as this type of reactors do not require mechanical mixing. These reactors generally offer a more efficient gas-to-liquid mass transfer while maintaining low gas and liquid flow rates due to the higher contact surface area between the gaseous substrate and the liquid film on the packing material. The influence of the liquid recirculation rate and the thickness of the liquid film on the mass transfer and the 
productivity of $\mathrm{CH}_{4}$ was studied during the biomethanation of $\mathrm{H}_{2}$ and $\mathrm{CO}_{2}$ using anaerobic sewage sludge as inoculum. ${ }^{103}$ A correlation between increasing productivities of $\mathrm{CH}_{4}$ and decreasing liquid recirculation rates was observed in this study, concluding that a high conversion (nearly $100 \%$ ) and productivity $\left(1.49 \mathrm{~L}_{\mathrm{CH} 4} / \mathrm{L} / \mathrm{d}\right)$ could be achieved without gas recirculation by just increasing the $\mathrm{H}_{2}$ loading rate while decreasing the liquid recirculation rate. Thus, trickle bed reactors seem a promising option for their application in syngas biomethanation as the plug flow regime of these reactors allows high gas loading rates while maintaining high productivities and conversion efficiencies. Nevertheless, as found in other processes, compromised stability of continuous processes due to channeling of the gaseous substrate through the packing material attributed to the excessive accumulation of microbial biofilm was observed during the biomethanation of $\mathrm{H}_{2}$ and $\mathrm{CO}_{2} \cdot{ }^{104}$ Kimmel et al. ${ }^{105}$ compared the performance of two trickle bed reactors with different diameters on the process of syngas biomethanation using a triculture of R. rubrum, M. formicicum and M. barkeri. The productivity of $\mathrm{CH}_{4}$ in the smaller reactor was observed to increase as the gas loading rate increased, reaching a maximum productivity of $2-3 \mathrm{mmol} \mathrm{CH}_{4} / \mathrm{L} / \mathrm{h}$. However, the productivity of the larger reactor barely reached $0.4 \mathrm{mmol} \mathrm{CH}_{4} / \mathrm{L} / \mathrm{h}$ at very low gas loading rates, showing a decreasing trend as the gas loading rate was raised. Apparently, the lower porosity along with the smaller size of the packing material used in the smaller reactor favored an enhanced productivity as the lower pore size of the packing promoted a better distribution of the liquid medium. Therefore, trickle bed reactors have been successfully applied to syngas biomethanation processes achieving high productivities and conversion efficiencies. Nevertheless, there are still certain aspects of the continuous operation of these reactors such as biofilm accumulation, porosity and the size of the packing material that need further study for attaining full exploitation of their potential. 
Table 2. Overview of syngas biomethanation process configurations and operating conditions.

\begin{tabular}{|c|c|c|c|c|c|c|c|c|c|c|c|c|c|}
\hline Microorganism & Reactor & $\begin{array}{l}\text { Operation } \\
\text { mode }\end{array}$ & $\begin{array}{c}\text { Gas } \\
\text { composition } \\
(\%)\end{array}$ & $\begin{array}{c}\text { Co- } \\
\text { substrate }\end{array}$ & $\begin{array}{c}\text { Gas } \\
\text { rec. rate } \\
(\mathbf{m l} / \mathbf{m i n})\end{array}$ & $\begin{array}{c}\text { Gas } \\
\text { flow } \\
\text { rate } \\
(\mathrm{ml} / \mathrm{min})\end{array}$ & $\begin{array}{c}\mathbf{H}_{2} \\
\text { flow rate } \\
(\mathbf{m m o l} / / / \mathbf{d})\end{array}$ & $\begin{array}{c}\text { CO } \\
\text { flow rate } \\
(\mathbf{m m o l} / / / \mathbf{d})\end{array}$ & $\begin{array}{l}\mathrm{CH}_{4} \text { prod. } \\
(\mathrm{mmol} / / \mathbf{d})\end{array}$ & $\begin{array}{c}\text { Yield }^{\mathrm{i}} \\
(\mathbf{m o l} / \mathbf{m o l})\end{array}$ & $\begin{array}{c}\mathbf{T} \\
\left(\mathbf{C}^{\circ}\right)\end{array}$ & pH & Ref. \\
\hline Cow pasture sludge & $\mathrm{BC}^{\mathrm{a}}$ & Batch & $\begin{array}{l}\mathrm{H}_{2} / \mathrm{CO}_{2} \\
(-)\end{array}$ & - & 300 & - & 1380 & - & 300 & $0.22-0.26$ & 55 & 7.4 & 107 \\
\hline Cow pasture sludge & $\mathrm{BC}^{\mathrm{a}}$ & Batch & $\begin{array}{l}\mathrm{CO} \\
(40)\end{array}$ & - & 300 & - & - & 480 & 120 & 0.25 & 55 & 7.4 & 107 \\
\hline $\begin{array}{l}\text { Sewage plant anaerobic } \\
\text { sludge }\end{array}$ & $\mathrm{TB}^{\mathrm{b}}$ & Cont. & $\begin{array}{l}\mathrm{H}_{2} / \mathrm{CO}_{2} \\
(-)\end{array}$ & - & - & n.d. & 268 & - & 66.5 & 0.248 & 37 & 7.2 & 103 \\
\hline $\begin{array}{l}\text { Fruit processing plant } \\
\text { granular sludge }\end{array}$ & $\mathrm{GL}^{\mathrm{c}}$ & Cont. & $\begin{array}{l}\mathrm{CO} \\
(41)\end{array}$ & - & 1150 & 57.5 & n.d. & - & $2.92^{\mathrm{h}}$ & 0.228 & 35 & 7.1 & 64 \\
\hline $\begin{array}{l}\text { Triculture (R. rubrum, M. } \\
\text { barkeri, M. formicicum) }\end{array}$ & $\mathrm{TB}^{\mathrm{b}}$ & Cont. & $\begin{array}{c}\mathrm{CO} / \mathrm{CO}_{2} / \mathrm{H}_{2} \\
(55.6 / 9.7 / 19.7)\end{array}$ & light & n.d. & 70 & n.d. & n.d. & $48-72$ & 0.2 & 37 & n.d. & 105 \\
\hline $\begin{array}{l}\text { Triculture (R. rubrum, M. } \\
\text { barkeri, M. formicicum) }\end{array}$ & $\mathrm{TB}^{\mathrm{b}}$ & Cont. & $\begin{array}{c}\mathrm{CO} / \mathrm{CO}_{2} / \mathrm{H}_{2} \\
(54.4 / 9.7 / 21.1)\end{array}$ & light & n.d. & 174 & n.d. & n.d. & 9.6 & 0.2 & 37 & n.d. & 105 \\
\hline Granular sludge & MOBB $^{\mathrm{d}}$ & Cont. & $\begin{array}{c}\mathrm{CO} / \mathrm{CO}_{2} / \mathrm{H}_{2} \\
(60 / 10 / 30)\end{array}$ & - & 600 & 100 & 24.2 & 54 & 73 & $0.6-0.8$ & $\begin{array}{l}35- \\
37\end{array}$ & $\begin{array}{l}5.8- \\
6.7\end{array}$ & 109 \\
\hline MSW sludge & $\mathrm{RMB}^{\mathrm{e}}$ & $\begin{array}{l}\text { Semi- } \\
\text { Cont. }\end{array}$ & $\begin{array}{c}\mathrm{CO} / \mathrm{CO}_{2} / \mathrm{H}_{2} \\
(55 / 10 / 20)\end{array}$ & $\begin{array}{c}3.4 \mathrm{~g} \\
\mathrm{COD} \\
\text { VFA's/1/d }\end{array}$ & 300 & n.d. & 7 & 15 & 8.3 & n.d. & 55 & n.d. & 110 \\
\hline Anaerobic sewage sludge & $\operatorname{STR}^{\mathrm{f}}$ & Cont. & $\begin{array}{c}\mathrm{H}_{2} / \mathrm{CO}_{2} \\
(-)\end{array}$ & - & n.d. & 700 & 1344 & - & 352.8 & n.d. & 37 & n.d. & 102 \\
\hline $\begin{array}{l}\text { Triculture (R. rubrum, } M \text {. } \\
\text { barkeri, M. formicicum) }\end{array}$ & $\mathrm{TB}^{\mathrm{b}}$ & Cont. & $\begin{array}{c}\mathrm{CO} / \mathrm{CO}_{2} / \mathrm{H}_{2} \\
(55.6 / 9.9 / 19.7)\end{array}$ & light & n.d. & 300 & n.d. & n.d. & 72 & 0.214 & 37 & $\begin{array}{l}6.8- \\
7.2\end{array}$ & 108 \\
\hline $\begin{array}{l}\text { Triculture (R. rubrum, M. } \\
\text { barkeri, M. formicicum) }\end{array}$ & $\mathrm{PBC}^{\mathrm{g}}$ & Cont. & $\begin{array}{c}\mathrm{CO} / \mathrm{CO}_{2} / \mathrm{H}_{2} \\
(55 / 9.6 / 20.4)\end{array}$ & light & n.d. & 80 & n.d. & n.d. & $4.8-7.2$ & 0.214 & 34 & $\begin{array}{l}6.8- \\
7.2 \\
\end{array}$ & 108 \\
\hline
\end{tabular}

${ }^{\mathrm{a}}$ bubble column; ${ }^{\mathrm{b}}$ trickle-bed; ${ }^{\mathrm{c}}$ gas-lift; ${ }^{\mathrm{d}}$ multi-orifice oscillatory baffled bioreactor; ${ }^{\mathrm{e}}$ reverse membrane bioreactor; ${ }^{\mathrm{f}}$ stirred tank reactor; ${ }^{\mathrm{g}}$ packed bubble

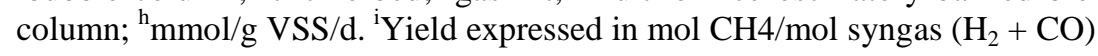




\subsubsection{Bubble column and gas-lift reactors}

The use of bubble columns and gas-lift reactors has also been studied in syngas biomethanation processes as they offer a number of benefits such as high gas-liquid interfacial area, high volumetric mass transfer coefficient, non-mechanical mixing and relatively low cost of operation. As there is no mechanical mixing, the mass transfer coefficient of these reactors generally depends on the gas flow rate and the size of the bubbles. The effect of these operational parameters on the mass transfer of $\mathrm{CO}$ was studied in both a bubble column and a gas-lift reactor, showing that the $\mathrm{K}_{\mathrm{L}} \mathrm{a}$ increases along with the increase of the gas flow rate and the decrease of the pore size of the column diffuser. ${ }^{106}$ The maximum $\mathrm{K}_{\mathrm{L}}$ a values reported for the bubble column and the gas-lift reactor were $78.8 \mathrm{~h}^{-1}$ and $91.1 \mathrm{~h}^{-1}$, respectively, when a gas flow rate of $5000 \mathrm{sccm}$ was combined with a $20 \mu \mathrm{m}$ bulb diffuser. ${ }^{106}$ Another common feature of these reactors is the need of applying a high gas recirculation rate in order to attain a relatively high conversion efficiency for sparingly soluble gases such as $\mathrm{H}_{2}$ and CO. Guiot et al. ${ }^{64}$ studied the effects of different gas recirculation rates during the biomethanation of $\mathrm{CO}$ in a gas-lift reactor using granular sludge. In these experiments, the insufficient gas holdup when gas recirculation was not applied resulted in a $\mathrm{CO}$ conversion efficiency as low as $4 \%$; however, when the gas recirculation-to-feed ratio was set to $18: 1$ the conversion efficiency increased to $70 \%$, obtaining an improvement of the productivity from $0.49 \mathrm{mmol} \mathrm{CH}_{4} / \mathrm{g} \mathrm{VSS} / \mathrm{d}$ to $2.55 \mathrm{mmol} \mathrm{CH}_{4} / \mathrm{g} \mathrm{VSS} / \mathrm{d}$. The increase in partial pressure of $\mathrm{CO}$ in the feed was also observed to have a positive impact on the productivity, although when both high gas recirculation rates and high CO partial pressure were applied the conversion efficiency dropped significantly due to the inhibitory effects of $\mathrm{CO} .{ }^{64}$ Similar results were obtained in batch experiments using a bubble column, as the productivity of $\mathrm{CH}_{4}$ from $\mathrm{H}_{2}$ and $\mathrm{CO}_{2}$ increased from $480 \mathrm{mmol} / \mathrm{L} / \mathrm{d}$ to $660 \mathrm{mmol} / \mathrm{L} / \mathrm{h}$ while raising the gas recirculation rate from 18 $\mathrm{L} / \mathrm{h}$ to $40 \mathrm{~L} / \mathrm{h} .{ }^{107}$ The continuous biomethanation of syngas has also been tested in a packed bed bubble 
column using a triculture of $R$. rubrum, M. formicicum and M. barkeri. ${ }^{108}$ A maximum conversion efficiency of $79 \%$ was reached at the lowest gas flow rate tested $(1.3 \mathrm{sccm})$ without gas recirculation, obtaining a rather low productivity of $\mathrm{CH}_{4}$ of around $0.2 \mathrm{mmol} / \mathrm{L} / \mathrm{h} .{ }^{108}$ Higher productivities $(0.4 \mathrm{mmol}$ $\mathrm{CH}_{4} / \mathrm{L} / \mathrm{h}$ ) could be achieved when raising the gas flow rate to $13.3-16.6 \mathrm{sccm}$; this however had a dramatic impact on the conversion efficiency as it dropped from $79 \%$ to $20-25 \%$. The authors concluded that the low productivity was caused by mass transfer limitations and the high porosity of the packing material given the low $\mathrm{K}_{\mathrm{L}}$ a value obtained $\left(3.5 \mathrm{~h}^{-1}\right)$. It seems that despite the simplicity of the design of these reactors, each of them has a good potential for their application in syngas biomethanation processes. However, there are several key operational parameters that need to be optimized in order to achieve a high productivity of $\mathrm{CH}_{4}$ while maintaining relatively high conversion efficiencies.

\subsubsection{Other reactor designs}

Other reactor designs have also been studied for improving the productivity of $\mathrm{CH}_{4}$ in syngas biomethanation processes by either overcoming the mass transfer limitations or increasing the concentration of cells in the bioreactor. A novel multi-orifice oscillatory baffled bioreactor with a unique baffle design for improving both mixing and mass transfer rates was fully characterized and

tested for the biomethanation of syngas using a mesophilic granular sludge as inoculum. ${ }^{109}$ The maximum productivity achieved with this bioreactor was $73 \mathrm{mmol} \mathrm{CH}_{4} / \mathrm{L} / \mathrm{d}$ at the maximum flow rate tested $(100 \mathrm{sccm})$. Nonetheless, as the gas loading rate was raised the conversion efficiency dropped as a result of the intensive mixing at high flow rates. Another reactor design intended to achieve total retention of cells into the bioreactor was also studied for its application in syngas biomethanation. This design consisted in a reverse membrane bioreactor, in which the microorganisms from a thermophilic 
MSW sludge were membrane encased prior to their inoculation in the bioreactor. ${ }^{110}$ The maximum productivity of $\mathrm{CH}_{4}$ reported for the biomethanation of solely syngas was $0.109 \mathrm{~L}_{\mathrm{CH} 4} / \mathrm{L} / \mathrm{d}$ when using a gas flow rate of $200 \mathrm{sccm}$, which was comparable to the productivity of an analogous reactor operated with free cells. ${ }^{110}$ However, the increase of the gas loading rate and the organic loading rate by addition of VFA's as co-substrate resulted in a sharp increase in the productivity of $\mathrm{CH}_{4}(0.186 \mathrm{~L} / \mathrm{L} / \mathrm{d})$ in the reverse membrane reactor, whereas in the free cells reactor the productivity gradually decreased to $0.046 \mathrm{~L}_{\mathrm{CH} 4} / \mathrm{L} / \mathrm{d}$ as the cells were washed out due to the more stringent conditions. ${ }^{110}$ Thus, the use of these membranes seems to effectively maintain a high concentration of cells in the bioreactor under harsh conditions, yet the effect of the membranes on the transport of the gaseous substrates to the microorganisms still remains to be investigated.

As shown in this section, the productivity of $\mathrm{CH}_{4}$ is highly dependent on the particular process configuration and type of reactor. A high productivity of $\mathrm{CH}_{4}$ can be achieved in each type of reactor under specific process configurations. Generally, the most influential parameters affecting the productivity in continuous processes are the concentration of cells, the gas-to-liquid mass transfer, the gas and liquid flow rates, the recycle of these streams and the mixing regime. Nevertheless, the relevance of these parameters is different for each type of reactor. A common feature of stirred tank reactors, bubble columns and gas-lift reactors is that for a given gas loading rate there is a maximum conversion efficiency threshold as a result of the mixed-flow regime of these reactors when high gas inflow and gas recirculation rates are applied. In turn, trickle-bed reactors seem to outperform the other type of reactors in several aspects due to their plug-flow regime. However, the application of microbubble dispersion in stirred tank reactors, bubble columns and gas-lift reactors, not studied yet in syngas biomethanation processes, could enhance significantly the mass transfer and hence the 
REVIEW ON SYNGAS BIOMETHANATION

performance of these reactors. Other aspects of the operation of these reactors such as scaling-up issues or economic considerations for each of the process configurations discussed, which have not been accounted for here, may also play a crucial role when it comes to determine the feasibility of these processes.

\subsection{Kinetics and modeling of syngas biomethanation processes}

Mathematical modeling of bioprocesses is usually applied in order to simulate and predict the outcome of different process configuration, as well as to optimize the process in terms of yield and productivity of the desirable product(s). Unstructured models are perhaps the most simplistic expression of mathematical models, using only a few state variables for describing the concentration profiles of microbial biomass, substrates and products. ${ }^{111}$ However, unstructured kinetic models are frequently used as they are simple and can successfully simulate the effects of the main variables on the microbial growth and the productivity in batch and continuous processes, being thus a valuable tool for design and operation of bioprocesses.

Kinetic models used so far for the determination of the kinetic properties of several syngas-converting pure cultures under different fermentation conditions and process configurations are shown in table 3. Vega et al. ${ }^{112}$ determined the kinetics of the growth of the acetogen $R$. productus on $\mathrm{CO}$ using a modified Monod equation in order to simulate the inhibitory effects of high $\mathrm{P}_{\mathrm{CO}}$. This model was then used for studying the conversion rate of $\mathrm{CO}$ as a function of the gas loading rate and the volumetric mass transfer coefficient in a stirred tank reactor and a bubble column. The growth kinetics of the acetogen $C$. ljungdahlii were determined using several dual-substrate kinetic models in order to study the effects of the initial pressure of syngas on the simultaneous consumption of $\mathrm{H}_{2}$ and $\mathrm{CO} .{ }^{113}$ Among 
all kinetic models tested in this study, the combination of Luong and Monod kinetics was found to give the best fitting for simulating growth on mixed substrates. Other kinetic models based on different equations have also been proposed. For instance, the kinetic parameters of the growth of C. ljungdahlii on $\mathrm{CO}$ and syngas were also determined using the Andrew equation and a novel equation for simulating microbial growth, cell decay and the inhibition of $\mathrm{CO} .{ }^{114}$ Hydrogenogenic cultures have also been studied using kinetic models in order to determine the optimum process parameters for the continuous production of $\mathrm{H}_{2}$. A Monod chemostat model was used to determine the kinetic parameters of $R$. rubrum growing on $\mathrm{CO}$ during washout experiments in a stirred tank reactor with dual impellers. ${ }^{99}$ The productivity of $\mathrm{H}_{2}$ was then optimized by using this model to determine the optimum dilution rate for the particular process configuration of this reactor. Another hydrogenogen, $C$. hydrogenoformans, was characterized kinetically using the Han and Levenspiel model in order to study the effects of the $\mathrm{P}_{\mathrm{CO}}$ and the influence of the ratio of substrate/biomass on the activity of the culture. ${ }^{115}$ The growth kinetics of other relevant microbial groups in syngas biomethanation processes such as methanogenic archaea have also been evaluated using a number of kinetic models based on Monod kinetics, the Andrew equation and a modified Gompertz model, among others. ${ }^{116-119}$ However, the influence of the partial pressure of $\mathrm{CO}$ on the kinetics of this microbial group has not been determined yet, as most of these studies have been carried out in the frame of anaerobic digestion processes.

Despite all microbial groups typically found in a syngas-converting microbial consortium have been characterized using kinetic models, a kinetic model able to describe the simultaneous growth of these microbial groups in syngas biomethanation processes has not been developed yet. The development of such a model, including e.g. the kinetic competition among microbial groups or the effects of the operating parameters on the growth of each microbial group, could contribute to improving the criteria 
REVIEW ON SYNGAS BIOMETHANATION

Table 3. Unstructured kinetic models used for several acetogens, hydrogenogens and methanogens.

\begin{tabular}{|c|c|c|c|c|c|c|}
\hline Microorganism & $\begin{array}{l}\text { Kinetic } \\
\text { model }\end{array}$ & Growth rate/Substrate-uptake rate equation & $\mu_{\max }$ & $\begin{array}{c}\text { Empirical consta } \\
K_{S}\end{array}$ & $K_{i}$ & Ref. \\
\hline R. productus & Andrew & $\mu=\frac{\mu_{\max } P_{C O}^{L}}{K_{S}+P_{C O}^{L}+\frac{\left(P_{C O}^{L}\right)^{2}}{W}}$ & $0.21 h^{-1}$ & $0.044 \mathrm{~atm}$ & $\begin{array}{c}P_{C O}^{L}<0,6 \mathrm{~atm} \\
W=\infty \\
P_{C O}^{L}>0,6 \mathrm{~atm} \\
W=3 \mathrm{~atm}\end{array}$ & 112 \\
\hline C. ljungdahlii & $\begin{array}{l}\text { Luong + } \\
\text { Monod }\end{array}$ & $\mu=\frac{\mu_{\max }}{2\left(\left(\frac{S_{C O}}{K_{S, C O}+S_{C O}}\right)\left(1-S_{C O} /_{S_{m}}\right)^{n}+\frac{S_{H 2}}{K_{S, H 2}+S_{H 2}}\right)}$ & $0.195 h^{-1}$ & $\begin{array}{l}C O=0.855 \mathrm{~atm} \\
H_{2}=0.412 \mathrm{~atm}\end{array}$ & $\begin{array}{c}S_{m}=0.743 \mathrm{~atm} \\
n=0.465\end{array}$ & 113 \\
\hline C. ljungdahlii & Andrew & $\mu=\frac{\mu_{\max , C O} C_{C O}^{*}}{K_{C O}+C_{C O}^{*}+\left(C_{C O}^{*}\right)^{2} / K_{i}}$ & $0.022 h^{-1}$ & $0.078 \mathrm{mmol} \mathrm{CO} / \mathrm{l}$ & $2 \mathrm{mmol} \mathrm{CO} / \mathrm{l}$ & 114 \\
\hline R. rubrum & Monod & $\mu=\frac{\mu_{\max } C_{S}}{K_{S}+C_{S}}$ & $0.0225 h^{-1}$ & $0.13 \mathrm{~g} \mathrm{CO} / \mathrm{l}$ & - & 99 \\
\hline C. hydrogenoformans & $\begin{array}{l}\text { Han and } \\
\text { Levenspiel }\end{array}$ & $k=k_{\max }\left(1-\frac{S}{S_{I}}\right)^{n} \frac{S}{S+K_{m}\left(1-\frac{S}{S_{I}}\right)^{m}}$ & $\begin{array}{l}8.2 \mathrm{~mol} \mathrm{CO} \\
/ g \mathrm{VSS} / \mathrm{d}\end{array}$ & $2.1 m M$ & $\begin{array}{c}S_{I}=1.37 m M \\
n=1.4 m=4.7\end{array}$ & 115 \\
\hline M. barkeri 227 & Andrew & $\mu=\frac{\mu_{\max , a c} S_{a c}}{K_{S, a c}+S_{a c}+\left(S_{a c}\right)^{2} / K_{i}}$ & $0.038 h^{-1}$ & $1.75 \mathrm{~g} \mathrm{ac} / \mathrm{l}$ & $7.37 \mathrm{gac} / \mathrm{l}$ & 117 \\
\hline M. barkeri $M S$ & Andrew & $\mu=\frac{\mu_{\max , a c} S_{a c}}{K_{S, a c}+S_{a c}+\left(S_{a c}\right)^{2} / K_{i}}$ & $0.63 h^{-1}$ & $100 \mathrm{gac} / l$ & $0.46 \mathrm{gac} / \mathrm{l}$ & 117 \\
\hline M. mazei S6 & Andrew & $\mu=\frac{\mu_{\max , a c} S_{a c}}{K_{S, a c}+S_{a c}+\left(S_{a c}\right)^{2} / K_{i}}$ & $0.029 h^{-1}$ & $1.00 \mathrm{~g} \mathrm{ac} / \mathrm{l}$ & $48.66 \mathrm{gac} / l$ & 117 \\
\hline M. thermoautotrophicum & Monod & $\mu=\frac{\mu_{\max } C_{S}}{K_{S}+C_{S}}$ & $0.69 h^{-1}$ & $\begin{array}{c}H_{2}=20 \% \\
C O_{2}=11 \%\end{array}$ & - & 116 \\
\hline
\end{tabular}


for the selection of operational parameters and easing optimization tasks in syngas biomethanation processes. Additionally, the inclusion of microbial interactions in the model could provide a certain control over the metabolic pathways dominating the microbial consortium. Nonetheless, a more complex model structure would be required in order to include the microbial interactions, thus complicating the estimation of the kinetic parameters describing the behavior of the microbial consortium. More structured modeling approaches that intended to describe the metabolic network of mixed culture-based processes have been proposed on the perspective of modeling anaerobic digestion processes ${ }^{120}$ or the product distribution in mixed culture fermentations. ${ }^{121}$ The only attempt of modeling the metabolic network of syngas biomethanation processes has been carried out based on a flux balance analysis approach, although the low number of components of the metabolic network monitored over time limited the accuracy of the model. ${ }^{109}$ However, this work sets a precedent in modeling of syngas biomethanation processes. Research in this direction is thus encouraged here given the potential of these models for the control and optimization of syngas biomethanation processes.

\section{Future Perspectives}

A significant research effort is being made worldwide in order to develop efficient processes for the production of biomethane from agricultural, domestic and industrial waste streams. This is of particular importance to several European countries currently showing an increasing interest in the production of biomethane, as it can contribute to offset the decreasing trend of production of natural gas and reduce their dependency on imported natural gas supplies. Several process configurations based on the syngas platform are being explored for increasing the share of biomethane to be used as a vehicle fuel or injected into the natural gas grid. A combined process of gasification and syngas biomethanation 
presents a significant potential as it offers the possibility of producing renewable methane from a wide array of waste streams regardless of their recalcitrance, broadening the spectrum of biomasses currently available to anaerobic digestion systems. In the near future, the biomethanation of syngas could become a suitable alternative for increasing the flexibility of gasification plants exploiting syngas for heat and electricity production. As opposed to the catalytic methanation process, the biological conversion of syngas to methane could be economically feasible for small-scale gasification plants due to its lower operational costs, which would provide an alternative outlet to the excess energy generated during periods of low heat and electricity demand. Other process configurations considered include the integration of anaerobic digestion and syngas biomethanation processes as their combination could result in a much higher biomass conversion efficiency and methane productivity. The gasification of either source-separated organic waste or solid digestate and re-injection of syngas into the bioreactor would certainly enhance the productivity of methane, achieving a nearly complete conversion of the biomass. However, the overall efficiency of the process could be compromised by the high moisture content of the solid digestate as an intensive drying process would be required in order to lower its moisture content to the optimal range. Therefore, regardless of the process configuration considered, there are still several challenges to be overcome in both the gasification of biomass and the biomethanation of syngas in order for these technologies to be commercially applicable.

Research on syngas biomethanation processes have undergone a considerable progress over the last years, evolving from the early pure culture-based studies aiming at understanding the metabolism of carboxydotrophic microorganisms to the current mixed culture-based approach for its industrial exploitation in the bioenergy sector. The continuous biomethanation of syngas has so far been successfully applied in a number of bioreactor designs and process configurations, achieving high yield 
and conversion efficiency for both $\mathrm{CO}$ and $\mathrm{H}_{2} / \mathrm{CO}_{2}$. Nevertheless, the performance of the bioreactors could still be further improved in order to achieve a higher conversion efficiency and productivity. Recent advances in the design of hollow fiber membrane reactors and microbubble spargers have been applied in other syngas fermentation processes, and seem a promising way for overcoming the mass transfer limitation. More research is also necessary in order to improve our knowledge on microbial consortia-driven processes. In this sense, adopting a cross-disciplinary approach is crucial for understanding the nature of the metabolic interactions in microbial consortia, and how these are affected by changes in the operational conditions of continuous processes. Important advances have been made so far in characterizing the effects of the operating conditions on the performance of microbial consortia, finding common patterns of activity on microbial consortia originated from different sources. However, further studies are still necessary in this area in order to find possible interactions between influencing factors, and to correlate these effects to the behavior of the population dynamics of microbial consortia. The potential of modelling tools for the control and optimization of mixed culture-based bioprocesses has also been discussed here. This area still remains practically unexplored in syngas biomethanation processes. However, the development of new models capable of describing the effects of the operating conditions on the behavior of mixed cultures could contribute to achieve a higher level of control over the performance of continuous processes.

The progress achieved over the last years opens good perspectives for the further development of syngas biomethanation processes. However, this technology has not reached commercial application yet, mainly due to the relatively high sales prices that are needed to supporting it. ${ }^{122}$ This can be overcome if a) syngas biomethanation occurs in the frame of an already industrial gasification activity, i.e. in Combined Heat and Power plants and b) further advancing the syngas biomethanation process 
targeting higher productivities than the ones achieved so far. Nowadays, where exploitation of the residual biomass is more than ever imperative, syngas biomethanation should be re-visited. Future advances in the areas outlined here will contribute to overcome the current limitations of the process, unlocking thus the potential of this technological application.

\section{Acknowledgements}

This work was financially supported by the Technical University of Denmark (DTU) and Innovation Foundation-DK in the frame of SYNFERON project.

\section{References}

1. Sorda G, Banse M, Kemfert C. An overview of biofuel policies across the world. Energy Policy. 38: 6977-88 (2010).

2. Munasinghe PC, Khanal SK. Biomass-derived syngas fermentation into biofuels: Opportunities and challenges. Bioresour Technol. 101: 5013-22 (2010).

3. Köpke M, Mihalcea C, Bromley JC, Simpson SD. Fermentative production of ethanol from carbon monoxide. Curr Opin Biotechnol. 22: 3, 320-5 (2011).

4. Mohammadi M, Najafpour GD, Younesi H, Lahijani P, Uzir MH, Mohamed AR. Bioconversion of synthesis gas to second generation biofuels: A review. Renew Sustain Energy Rev. 15: 425573 (2011).

5. Devarapalli M, Atiyeh HK. A review of conversion processes for bioethanol production with a focus on syngas fermentation. Biofuel Res J. 7: 268-80 (2015).

6. Kennes D, Abubackar HN, Diaz M, Veiga MC, Kennes C. Bioethanol production from biomass: Carbohydrate vs syngas fermentation. J Chem Technol Biotechnol. 91: 2, 304-17 (2016).

7. Verma D, Singla A, Lal B, Sarma PM. Conversion of biomass-generated syngas into nextgeneration liquid transport fuels through microbial intervention: potential and current status. Curr Sci. 110: 3, 329-36 (2016). 
REVIEW ON SYNGAS BIOMETHANATION

8. Rittmann SKMR, Lee HS, Lim JK, Kim TW, Lee JH, Kang SG. One-carbon substrate-based biohydrogen production: Microbes, mechanism, and productivity. Biotechnol Adv. 33: 165-77 (2015).

9. Bredwell MD, Srivastava P, Worden RM. Reactor design issues for synthesis-gas fermentations. Biotechnol Prog. 15: 834-44 (1999).

10. Daniell J, Köpke M, Simpson S. Commercial Biomass Syngas Fermentation. Energies. 5: 5372417 (2012).

11. Bengelsdorf FR, Straub M, Dürre P. Bacterial synthesis gas (syngas) fermentation. Environ Technol. 34: 1639-51 (2013).

12. Drzyzga O, Revelles O, Durante-rodríguez G, Díaz E, García JL, Prieto A. New challenges for syngas fermentation: towards production of biopolymers. J Chem Technol Biotechnol. 90: 1735$51(2015)$.

13. Bertsch J, Müller V. Bioenergetic constraints for conversion of syngas to biofuels in acetogenic bacteria. Biotechnol Biofuels. 8: 210, 1-12 (2015).

14. Liew F, Martin E, Tappel R, Heijstra B, Mihalcea C, Köpke M. Gas Fermentation - A Flexible Platform for Commercial Scale Production of Low Carbon Fuels and Chemicals from Waste and Renewable Feedstocks. Front Microbiol. 7: 1-28 (2016).

15. Dürre P. Butanol formation from gaseous substrates. FEMS Microbiol Lett. 363: 6, 1-7 (2016).

16. Thrän D et al. Biomethane - status and factors affecting market development and trade. IEA Task 40 and Task 37 Joint Study (2014).

17. Lantz M, Svensson M, Björnsson L, Börjesson P. The prospects for an expansion of biogas systems in Sweden - Incentives, barriers and potentials. Energy Policy. 35: 1819-29 (2007).

18. Börjesson P, Mattiasson B. Biogas as a resource-efficient vehicle fuel. Trends Biotechnol. 26: 713 (2008).

19. IEA Bioenergy Task 37 - Country Reports Summary 2015. IEA Bioenergy Task 37 (2016).

20. Lide DR. CRC Handbook of Chemistry and Physics. 90th ed. Lide DR, Haynes WM, editors. Journal of the American Chemical Society. CRC Press, 2804 p. (2009).

21. Demirel Y. Energy: Production, Conversion, Storage, Conservation, and Coupling. Springer Science \& Business Media, 508 p. (2012).

22. Holm-Nielsen JB, Al Seadi T, Oleskowicz-Popiel P. The future of anaerobic digestion and biogas utilization. Bioresour Technol. 100: 5478-84 (2009). 
REVIEW ON SYNGAS BIOMETHANATION

23. Kopyscinski J, Schildhauer TJ, Biollaz SMA. Production of synthetic natural gas ( SNG ) from coal and dry biomass - A technology review from 1950 to 2009. Fuel. 89: 1763-83 (2010).

24. Kumar A, Jones DD, Hanna M a. Thermochemical Biomass Gasification: A Review of the Current Status of the Technology. Energies. 2: 556-81 (2009).

25. Redl S, Diender M, Ølshøj T, Sousa DZ, Toftgaard A. Exploiting the potential of gas fermentation. Ind Crop Prod. 106: 21-30 (2017).

26. Xia A, Cheng J, Murphy JD. Innovation in biological production and upgrading of methane and hydrogen for use as gaseous transport biofuel. Biotechnol Adv. 34: 5, 451-72 (2016).

27. Kleerebezem R, van Loosdrecht MC. Mixed culture biotechnology for bioenergy production. Curr Opin Biotechnol. 18: 207-12 (2007).

28. Marshall CW, LaBelle E V., May HD. Production of fuels and chemicals from waste by microbiomes. Curr Opin Biotechnol. 24: 391-7 (2013).

29. Rönsch S, Schneider J, Matthischke S, Schlüter M, Götz M, Lefebvre J, et al. Review on methanation - From fundamentals to current projects. Fuel. 166: 276-96 (2016).

30. Li H, Larsson E, Thorin E, Dahlquist E, Yu X. Feasibility study on combining anaerobic digestion and biomass gasification to increase the production of biomethane. Energy Convers Manag. 100: 212-9 (2015).

31. Brown RC. Hybrid Thermochemical / Biological Processing. Putting the Cart Before the Horse? 136: 947-56 (2007).

32. Klasson KT, Ackerson MD, Clausen EC, Gaddy JL. Bioconversion of synthesis gas into liquid or gaseous fuels. Enzyme Microb Technol. 14: 602-8 (1992).

33. Batstone DJ, Virdis B. The role of anaerobic digestion in the emerging energy economy. Curr Opin Biotechnol. 27: 142-9 (2014).

34. Noike T, Endo G, Chang JE, Yaguchi J, Matsumoto J. Characteristics of carbohydrate degradation and the rate-limiting step in anaerobic digestion. Biotechnol Bioeng. 27: 1482-9 (1985).

35. Guiot SR, Cimpoia R, Dath L, Ollier J, Das R, Sancho Navarro S. Chapter 1.10. Anaerobic digestion fully enhanced by merging the biomethanation of syngas from solid digestate. In: Poggi-Varaldo HM, Bretón-Deval LM, Camacho-Pérez B, Escamilla-Alvarado C, EscobedoAcuña G, Hernández-Flores G, et al., editors. Environmental Biotechnology and Engineering. Ed. Cinves. Mexico D.F., Mexico, p. 84-91 (2014).

36. Shen Y, Linville JL, Urgun-Demirtas M, Schoene RP, Snyder SW. Producing pipeline-quality biomethane via anaerobic digestion of sludge amended with corn stover biochar with in-situ $\mathrm{CO}_{2}$ 
removal. Appl Energy. 158: 300-9 (2015).

37. Fabbri D, Torri C. Linking pyrolysis and anaerobic digestion (Py-AD) for the conversion of lignocellulosic biomass. Curr Opin Biotechnol. 38: 167-73 (2016).

38. Xu D, Tree DR, Lewis RS. The effects of syngas impurities on syngas fermentation to liquid fuels. Biomass and Bioenergy. 35: 2690-6 (2011).

39. Ramachandriya KD, Kundiyana DK, Sharma AM, Kumar A, Atiyeh HK, Huhnke RL et al. Critical factors affecting the integration of biomass gasification and syngas fermentation technology. AIMS Bioeng. 3: 188-210 (2016).

40. Inman RE, Ingersoll RB. Note on the Uptake of Carbon Monoxide by Soil Fungi. J Air Pollut Control Assoc. 21: 646-7 (1971).

41. Chappelle EW. Carbon monoxide oxidation by algae. Biochim Biophys Acta. 62: 45-62 (1962).

42. Pakpour F, Najafpour G, Tabatabaei M, Tohidfar M, Younesi H. Biohydrogen production from CO-rich syngas via a locally isolated Rhodopseudomonas palustris PT. Bioprocess Biosyst Eng. 37: 923-30 (2014).

43. Alves JI, van Gelder AH, Alves MM, Sousa DZ, Plugge CM. Moorella stamsii sp. nov., a new anaerobic thermophilic hydrogenogenic carboxydotroph isolated from digester sludge. Int J Syst Evol Microbiol. 63: 4072-6 (2013).

44. Sokolova TG, Jeanthon C, Kostrikina NA, Chernyh NA, Lebedinsky A V., Stackebrandt E, et al. The first evidence of anaerobic $\mathrm{CO}$ oxidation coupled with $\mathrm{H}_{2}$ production by a hyperthermophilic archaeon isolated from a deep-sea hydrothermal vent. Extremophiles. 8: $317-$ 23 (2004).

45. Parshina SN, Sipma J, Nakashimada Y, Henstra AM, Smidt H, Lysenko AM, et al. Desulfotoculum carboxydivorans sp. nov., a novel sulfate-reducing bacterium capable of growth at 100\% CO. Int J Syst Evol Microbiol. 55: 2159-65 (2005).

46. Henstra AM, Dijkema C, Stams AJM. Archaeoglobus fulgidus couples CO oxidation to sulfate reduction and acetogenesis with transient formate accumulation. Environ Microbiol. 9: 1836-41 (2007).

47. Bernalier A, Willems A, Leclerc M, Rochet V, Collins MD. Ruminococcus hydrogenotrophicus sp. nov., a new $\mathrm{H}_{2} / \mathrm{CO}_{2}$-utilizing acetogenic bacterium isolated from human feces. Arch Microbiol. 166: 176-83 (1996).

48. Rother M, Metcalf WW. Anaerobic growth of Methanosarcina acetivorans C2A on carbon monoxide: an unusual way of life for a methanogenic archaeon. Proc Natl Acad Sci U S A. 101: 16929-34 (2004). 
REVIEW ON SYNGAS BIOMETHANATION

49. Cord-Ruwisch R, Seitz H-J, Conrad R. The capacity of hydrogentrophic anaerobic bacteria to compete for traces of hydrogen depends on the redox potential of the electron acceptor. Arch Microbiol. 149: 350-7 (1988).

50. Mörsdorf G, Frunzke K, Gadkari D, Meyer O. Microbial growth on carbon monoxide. Biodegradation. 3: 61-82 (1992).

51. Diekert G, Hansch M, Conrad R. Acetate synthesis from $2 \mathrm{CO}_{2}$ in acetogenic bacteria: is carbon monoxide an intermediate? Arch Microbiol. 138: 224-8 (1984).

52. Oelgeschläger E, Rother $\mathrm{M}$. Carbon monoxide-dependent energy metabolism in anaerobic bacteria and archaea. Arch Microbiol. 190: 257-69 (2008).

53. Techtmann SM, Colman AS, Robb FT. "That which does not kill us only makes us stronger": The role of carbon monoxide in thermophilic microbial consortia. Environ Microbiol. 11: 102737 (2009).

54. Ferry JG. CO Dehydrogenase. Annu Rev Microbiol. 49: 305-33 (1995).

55. Sipma J, Henstra AM, Parshina SM, Lens PN, Lettinga G, Stams AJM. Microbial CO conversions with applications in synthesis gas purification and bio-desulfurization. Crit Rev Biotechnol. 26: 41-65 (2006).

56. Drake HL, Küsel K, Matthies C. Acetogenic Prokaryotes. In: Prokaryotes. Springer, New York, p. 354-420(2006).

57. Zeikus AJG, Kerby R, Krzycki JA. Single-Carbon Chemistry of Acetogenic and Methanogenic Bacteria. Am Assoc Adv Sci. 227: 4691, 1167-73 (2011).

58. Liu Y, Whitman WB. Metabolic, Phylogenetic, and Ecological Diversity of the Methanogenic Archaea. Ann N Y Acad Sci. 1125: 171-89 (2008).

59. Tiquia-Arashiro SM. Thermophilic Carboxydotrophs and their Applications in Biotechnology. Springer International Publishing, 131 p. (2014).

60. Mohammadi M, Younesi H, Najafpour G, Mohamed AR. Sustainable ethanol fermentation from synthesis gas by Clostridium ljungdahlii in a continuous stirred tank bioreactor. J Chem Technol Biotechnol. 87: 6, 837-43 (2012).

61. Worden RM, Grethlein AJ, Zeikus JG, Datta R. Butyrate Production from Carbon Monoxide by Butyribacteriurn methylotrophicurn. Appl Biochem Biotechnol. 20: 1, 687-99 (1989).

62. Fernández-Naveira Á, Abubackar HN, Veiga MC, Kennes C. Efficient butanol-ethanol (B-E) production from carbon monoxide fermentation by Clostridium carboxidivorans. Appl Microbiol Biotechnol. 3361-70 (2016). 
63. Thauer RK, Jungermann K, Decker K. Energy conservation in chemotrophic anaerobic bacteria. Bacteriol Rev. 41: 100-80 (1977).

64. Guiot SR, Cimpoia R. Potential of Wastewater-Treating Anaerobic Granules for Biomethanation of Synthesis Gas. Environ Sci Technol. 45: 2006-12 (2011).

65. Navarro SS, Cimpoia R, Bruant G, Guiot SR. Specific inhibitors for identifying pathways for methane production from carbon monoxide by a nonadapted anaerobic mixed culture. 415: 40715 (2014).

66. Sipma J, Lens PNL, Stams a. JM, Lettinga G. Carbon monoxide conversion by anaerobic bioreactor sludges. FEMS Microbiol Ecol. 44: 271-7 (2003).

67. Luo G, Wang W, Angelidaki I. Anaerobic digestion for simultaneous sewage sludge treatment and CO biomethanation: process performance and microbial ecology. Environ Sci Technol. 47: 10685-93 (2013).

68. Wang W, Xie L, Luo G, Zhou Q, Angelidaki I. Performance and microbial community analysis of the anaerobic reactor with coke oven gas biomethanation and in situ biogas upgrading. Bioresour Technol. 146: 234-9 (2013).

69. Boone DR, Johnson RL, Liu Y. Diffusion of the interspecies electron carriers H2 and formate in methanogenic ecosystems and its implications in the measurement of $\mathrm{Km}$ for $\mathrm{H} 2$ or formate uptake. Appl Env Microbiol. 55: 1735-41 (1989).

70. Navarro SS, Cimpoia R, Bruant G, Guiot SR. Biomethanation of Syngas Using Anaerobic Sludge: Shift in the Catabolic Routes with the CO Partial Pressure Increase. Front Microbiol. 7: $1-13$ (2016).

71. Rotaru A-E, Shrestha PM, Liu F, Shrestha M, Shrestha D, Embree M, et al. A new model for electron flow during anaerobic digestion: direct interspecies electron transfer to Methanosaeta for the reduction of carbon dioxide to methane. Energy Environ Sci. 7: 408-15 (2014).

72. Parshina SN, Kijlstra S, Henstra AM, Sipma J, Plugge CM, Stams AJM. Carbon monoxide conversion by thermophilic sulfate-reducing bacteria in pure culture and in co-culture with Carboxydothermus hydrogenoformans. Appl Microbiol Biotechnol. 68: 390-6 (2005).

73. Rajagopal BS, Lespinat PA, Fauque G, LeGall J, Berlier YM. Mass-spectrometric studies of the interrelations among hydrogenase, carbon monoxide dehydrogenase, and methane-forming activities in pure and mixed cultures of Desulfovibrio vulgaris, Desulfovibrio desulfuricans, and Methanosarcina barkeri. Appl Environ Microbiol. 55: 2123-9 (1989).

74. Stams AJM, Elferink SJWH, Westermann P. Metabolic Interactions Between Methanogenic Consortia and Anaerobic Respiring Bacteria. Adv Biochem Eng Biotechnol. 81: 31-56 (2003).

75. Stams a. JM, Plugge CM, de Bok F a M, van Houten BHGW, Lens P, Dijkman H, et al. 
Metabolic interactions in methanogenic and sulfate-reducing bioreactors. Water Sci Technol. 52: 13-20 (2005).

76. Sipma J, Lettinga G, Stams AJM, Lens PNL. Hydrogenogenic CO conversion in a moderately thermophilic $(55 \mathrm{C})$ sulfate-fed gas lift reactor: Competition for $\mathrm{CO}$-derived $\mathrm{H}_{2}$. Biotechnol Prog. 22: 1327-34 (2006).

77. Liu R, Hao X, Wei J. Function of homoacetogenesis on the heterotrophic methane production with exogenous $\mathrm{H}_{2} / \mathrm{CO}_{2}$ involved. Chem Eng J. 284: 1196-203 (2015).

78. Daniels L, Fuchs G, Thauer RK, Zeikus JG. Carbon Monoxide Oxidation by Methanogenic Bacteria. J Bacteriol. 132: 118-26 (1977).

79. Kerby R, Zeikus JG. Growth of Clostridium thermoaceticum on $\mathrm{H}_{2} / \mathrm{CO}_{2}$ or $\mathrm{CO}$ as energy source. Curr Microbiol. 8: 27-30 (1983).

80. Lorowitz WH, Bryant MP. Peptostreptococcus productus strain that grows rapidly with $\mathrm{CO}$ as the energy source. Appl Environ Microbiol. 47: 961-4 (1984).

81. Kerby RL, Ludden PW, Roberts GP. Carbon monoxide-dependent growth of Rhodospirillum rubrum. J Bacteriol. 177: 2241-4 (1995).

82. Henstra AM, Sipma J, Rinzema A, Stams AJM. Microbiology of synthesis gas fermentation for biofuel production. Curr Opin Biotechnol. 18: 200-6 (2007).

83. Ghosh S, Chowdhury R, Bhattacharya P. Mixed consortia in bioprocesses: role of microbial interactions. Appl Microbiol Biotechnol. 100: 4283-95 (2016).

84. Kundiyana DK, Wilkins MR, Maddipati P, Huhnke RL. Effect of temperature, $\mathrm{pH}$ and buffer presence on ethanol production from synthesis gas by "Clostridium ragsdalei". Bioresour Technol. 102: 5794-9 (2011).

85. Abubackar HN, Veiga MC, Kennes C. Biological conversion of carbon monoxide to ethanol: effect of $\mathrm{pH}$, gas pressure, reducing agent and yeast extract. Bioresour Technol. 114: 518-22 (2012).

86. Pereira FM, Alves MM, Sousa DZ. Effect of $\mathrm{pH}$ and pressure on syngas fermentation by anaerobic mixed cultures. In: 13th World Congress on Anaerobic Digestion. p. 1-4 (2013).

87. Conrad R, Wetter B. Influence of temperature on energetics of hydrogen metabolism in homoacetogenic, methanogenic, and other anaerobic bacteria. Arch Microbiol. 155: 1, 94-8 (1990).

88. Diender M, Pereira R, Wessels HJCT, Stams AJM, Sousa DZ. Proteomic Analysis of the Hydrogen and Carbon Monoxide Metabolism of Methanothermobacter marburgensis. Front Microbiol. 7: 1-10 (2016). 
REVIEW ON SYNGAS BIOMETHANATION

89. Alves JI, Stams AJM, Plugge CM, Alves MM, Sousa DZ. Enrichment of anaerobic syngasconverting bacteria from thermophilic bioreactor sludge. FEMS Microbiol Ecol. 86: 590-7 (2013).

90. Skidmore BE, Baker R a., Banjade DR, Bray JM, Tree DR, Lewis RS. Syngas fermentation to biofuels: Effects of hydrogen partial pressure on hydrogenase efficiency. Biomass and Bioenergy. 55: 156-62 (2013).

91. Lopes M, Alves JI, Arantes AL, Belo I, Sousa DZ, Alves MM. Hydrogenotrophic activity under increased $\mathrm{H}_{2} / \mathrm{CO}_{2}$ pressure: Effect on methane production and microbial community. $J$ Biotechnol. 208: Supplement, S57 (2015).

92. Ahmed A, Cateni BG, Huhnke RL, Lewis RS. Effects of biomass-generated producer gas constituents on cell growth, product distribution and hydrogenase activity of Clostridium carboxidivorans $\mathrm{P}^{\mathrm{T}}$. Biomass and Bioenergy. 30: 665-72 (2006).

93. Xu D, Lewis RS. Syngas fermentation to biofuels: Effects of ammonia impurity in raw syngas on hydrogenase activity. Biomass and Bioenergy. 45: 303-10 (2012).

94. Vega JL, Klasson KT, Kimmel DE, Clausen EC, Gaddy JL. Sulfur gas tolerance and toxicity of co-utilizing and methanogenic bacteria. Appl Biochem Biotechnol. 24-25: 329-40 (1990).

95. Guiot S, Cimpoia R, Sancho Navarro S, Prudhomme A, Filiatrault M. Anaerobic digestion for bio-upgrading syngas into renewable natural gas (methane). In: Proceedings of the 13th world congress on anaerobic digestion. Santiago de Compostela, p. 1-5 (2013).

96. Saxena J, Tanner RS. Effect of trace metals on ethanol production from synthesis gas by the ethanologenic acetogen, Clostridium ragsdalei. J Ind Microbiol Biotechnol. 38: 513-21 (2011).

97. Hu P. Thermodynamic, Sulfide, Redox Potential, and $\mathrm{pH}$ Effects on Syngas Fermentation. All Theses and Dissertations. Paper 2919. Brigham Young University (2011).

98. Orgill JJ, Atiyeh HK, Devarapalli M, Phillips JR, Lewis RS, Huhnke RL. A comparison of mass transfer coefficients between trickle-bed, Hollow fiber membrane and stirred tank reactors. Bioresour Technol. 133: 340-6 (2013).

99. Najafpour G, Younesi H, Mohamed AR. Continuous Hydrogen Production Via Fermentation of Synthesis Gas. Pet Coal. 45: 154-8 (2003).

100. Groher A, Weuster-botz D. Comparative reaction engineering analysis of different acetogenic bacteria for gas fermentation. J Biotechnol. 228: 82-94 (2016).

101. Ungerman AJ, Heindel TJ. Carbon Monoxide Mass Transfer for Syngas Fermentation in a Stirred Tank Reactor with Dual Impeller Configurations. Biotechnol Prog. 23: 613-20 (2007).

102. Wise DL, Cooney CL, Augenstein DC. Biomethanation: Anaerobic fermentation of $\mathrm{CO}_{2}, \mathrm{H}_{2}$ and 
CO to methane. Biotechnol Bioeng. 20: 1153-72 (1978).

103. Burkhardt M, Koschack T, Busch G. Biocatalytic methanation of hydrogen and carbon dioxide in an anaerobic three-phase system. Bioresour Technol. 178: 330-3 (2015).

104. Jee HS, Nishio N, Nagai S. Continuous methane production from hydrogen and carbon dioxide by Methanobacterium thermoautotrophicum in a fixed-bed reactor. J Ferment Technol. 66: 2358 (1988).

105. Kimmel DE, Klasson KT, Clausen EC, Gaddy JL. Performance of trickle-bed bioreactors for converting synthesis gas to methane. Appl Biochem Biotechnol. 28-29: 457-69 (1991).

106. Munasinghe PC, Khanal SK. Syngas fermentation to biofuel: Evaluation of carbon monoxide mass transfer coefficient $\left(\mathrm{k}_{\mathrm{L}} \mathrm{a}\right)$ in different reactor configurations. Biotechnol Prog. 26: 1616-21 (2010).

107. Bugante EC, Shimomura Y, Tanaka T, Taniguchi M, Oi S. Methane production from hydrogen and carbon dioxide and monoxide in a column bioreactor of thermophilic methanogens by gas recirculation. J Ferment Bioeng. 67: 419-21 (1989).

108. Klasson KT, Cowger JP, Ko CW, Vega JL, Clausen EC, Gaddy JL. Methane production from synthesis gas using a mixed culture of $R$. rubrum M. barkeri, and M. formicicum. Appl Biochem Biotechnol. 24-25: 317-28 (1990).

109. Pereira FM. Intensified Bioprocess for the Anaerobic Conversion of Syngas to Biofuels. Universidade do Minho (2014).

110. Westman S, Chandolias K, Taherzadeh M. Syngas Biomethanation in a Semi-Continuous Reverse Membrane Bioreactor (RMBR). Fermentation. 2: 1-12 (2016).

111. Almquist J, Cvijovic M, Hatzimanikatis V, Nielsen J, Jirstrand M. Kinetic models in industrial biotechnology - Improving cell factory performance. Metab Eng. 24: 38-60 (2014).

112. Vega JL, Clausen EC, Gaddy JL. Design of bioreactors for coal synthesis gas fermentations. Resour Conserv Recycl. 3: 149-60 (1990).

113. Mohammadi M, Mohamed AR, Najafpour GD, Younesi H, Uzir MH. Kinetic studies on fermentative production of biofuel from synthesis gas using Clostridium ljungdahlii. Sci World J. 2014: 1-8 (2014).

114. Younesi H, Najafpour G, Mohamed AR. Ethanol and acetate production from synthesis gas via fermentation processes using anaerobic bacterium, Clostridium ljungdahlii. Biochem Eng J. 27: 2, 110-9 (2005).

115. Zhao Y, Cimpoia R, Liu Z, Guiot SR. Kinetics of $\mathrm{CO}$ conversion into $\mathrm{H}_{2}$ by Carboxydothermus hydrogenoformans. Appl Microbiol Biotechnol. 91: 1677-84 (2011). 
116. Schönheit P, Moll J, Thauer RK. Growth Parameters $\left(\mathrm{K}_{\mathrm{s}}, \mu_{\max }, \mathrm{Y}_{\mathrm{s}}\right)$ of Methanobacterium thermoautotrophicum. Arch Microbiol. 127: 59-65 (1980).

117. Yang ST, Okos MR. Kinetic Study and Mathematical Modeling of Methanogenesis of Acetate Using Pure Cultures of Methanogens. Biotechnol Bioeng. 30: 661-7 (1987).

118. Ako OY, Kitamura Y, Intabon K, Satake T. Steady state characteristics of acclimated hydrogenotrophic methanogens on inorganic substrate in continuous chemostat reactors. Bioresour Technol. 99: 6305-10 (2008).

119. Pan X, Angelidaki I, Alvarado-Morales M, Liu H, Liu Y, Huang X, et al. Methane Production from Formate, Acetate and $\mathrm{H}_{2} / \mathrm{CO}_{2}$; focusing on kinetics and microbial characterization. Bioresour Technol. 218: 796-806 (2016).

120. Batstone D, Keller J, Angelidaki I, Kalyuzhnyi S., Pavlostathis S., Rozzi A, et al. The IWA Anaerobic Digestion Model No 1(ADM1). Water Sci Technol. 45: 10, 65-73 (2002).

121. Rodríguez J, Kleerebezem R, Lema JM, Van Loosdrecht MCM. Modeling product formation in anaerobic mixed culture fermentations. Biotechnol Bioeng. 93: 592-606 (2006).

122. Hoogendoorn A, van Kasteren H. Transportation Biofuels: novel pathways for the production of ethanol, biogas and biodiesel. Royal Society of Chemistry, Cambridge, 202 p. (2010). 